\title{
First evidence of a mid-Holocene earthquake-triggered megaturbidite south of the Chile Triple Junction
}

\author{
Loïc Piret a,*, Sebastien Bertrand ${ }^{\mathrm{a}}$, Catherine Kissel ${ }^{\mathrm{b}}$, Ricardo De Pol-Holz ${ }^{\mathrm{c}}$, \\ Alvaro Tamayo Hernando ${ }^{\mathrm{d}}$, Maarten Van Daele ${ }^{\mathrm{a}}$ \\ a Renard Centre of Marine Geology, Department of Geology, Ghent University, Krijgslaan 281 S8, 9000 Ghent, Belgium \\ b Laboratoire des Sciences du Climat et de l'Environnement/IPSL, CEA-CNRS-UVSQ Université Paris-Saclay, Avenue de la Terrasse, 91198 Gif-sur-Yvette, France \\ c GAIA-Antártica, Universidad de Magallanes, Avenida Bulnes 01855, Punta Arenas, Chile \\ d Facultad Ciencias Naturales Y Oceanográficas, Universidad de Concepción, Barrio Universitario, Concepción, Chile
}

\section{A R T I C L E I N F O}

\section{Article history:}

Received 14 June 2017

Received in revised form 11 January 2018

Accepted 15 January 2018

Available online 4 February 2018

\section{Keywords:}

Turbidite

Sediment provenance

Patagonia

Holocene

Earthquake

\begin{abstract}
A B S T R A C T
Megaturbidites have been the focus of many paleoseismic and paleoenvironmental studies because they can provide evidence for catastrophic and/or hazardous events with potentially major environmental implications. During a recent research cruise in Baker Fjord, Chile $\left(47^{\circ} 54^{\prime} \mathrm{S}-74^{\circ} 30^{\prime} \mathrm{W}\right)$, a megaturbidite was described between the Northern and Southern Patagonian Icefields. Here, we aim to determine the depositional processes of the megaturbidite and identify its origin. Based on the turbidite's location, a possible origin was the early Holocene drainage of paleo-lake General Carrera, which was recently proposed in the literature as having produced a Glacial Lake Outburst Flood (GLOF) that drained through Baker Fjord. Due to the fjord's location in a subduction zone, and close to the Chile Triple Junction, however, seismic activity must also be considered as a potential triggering mechanism. To achieve our goals, we undertook a multi-proxy analysis of sediment core MD07-3121, including sedimentology (grain size, loss-on-ignition, foraminifera counts), magnetic properties, bulk organic geochemistry, and radiocarbon dating, and we analysed bathymetric maps and sub-bottom profiles. Our grain-size results display a diagnostic fining upward trend and show evidence of seiching in the 733-cm-thick megaturbidite. The age of the event (5513-5211 cal yr BP) contradicts the hypothesis of an early Holocene GLOF origin. Bulk organic geochemical results indicate that the sediments that compose the turbidite are clearly of marine origin, which further goes against a GLOF origin. In addition, the megaturbidite is underlain by a $1136 \mathrm{~cm}$ thick mass transport deposit (MTD), also composed of marine sediments. According to the sub-bottom profiles, the MTD and the megaturbidite originate from the reworking of thick packages of sediment previously deposited on nearby sills and on the fjord's flanks. Furthermore, similar coeval deposits are found in an adjacent sub-basin. We therefore interpret these deposits to be triggered by an earthquake during the late mid-Holocene. While megathrust and intraslab earthquakes are possible in the region, we argue that a crustal earthquake is the most likely seismic trigger in the study area. This study reveals the first earthquake-triggered megaturbidite south of the Chile Triple Junction.
\end{abstract}

(c) 2018 Elsevier B.V. All rights reserved.

\section{Introduction}

Southern South America is a geologically highly active area. Due to the active subduction zone, the region frequently experiences large destructive earthquakes and explosive volcanic eruptions. In addition, its southern tip, Patagonia, is covered by two extensive icefields (the Northern and Southern Patagonian icefields; Fig. 1), which host some of the fastest retreating glaciers on Earth (Jansen et al., 2007). Fjord sediments in the area are therefore prone to containing event deposits related to earthquakes, volcanic eruptions or Glacial Lake Outburst

\footnotetext{
* Corresponding author.

E-mail address: Loic.Piret@Ugent.be (L. Piret).
}

Floods (GLOFs) (Lee et al., 2006; Lara, 2010; St-Onge et al., 2012; Van Daele et al., 2013; Fontijn et al., 2014).

The Patagonian fjord area, and the region between the two icefields in particular (Fig. 1), has attracted the attention of several groups of scientists in the last few years, due to its role in the drainage of extensive proglacial lakes during the last deglaciation (Glasser et al., 2016) and to the extreme modern salinity gradient of the fjord waters (González et al., 2013; Marín et al., 2013). The longest sediment core ever collected in the Baker-Martinez Fjord complex was obtained during the PACHIDERME research cruise aboard R/V Marion Dufresne in 2007. During preliminary description of the core onboard, a large $(>5 \mathrm{~m})$ turbidite was described in core MD07-3121 (Kissel and The Shipboard Scientific Party, 2007). In such a highly active environment, turbidites can be 


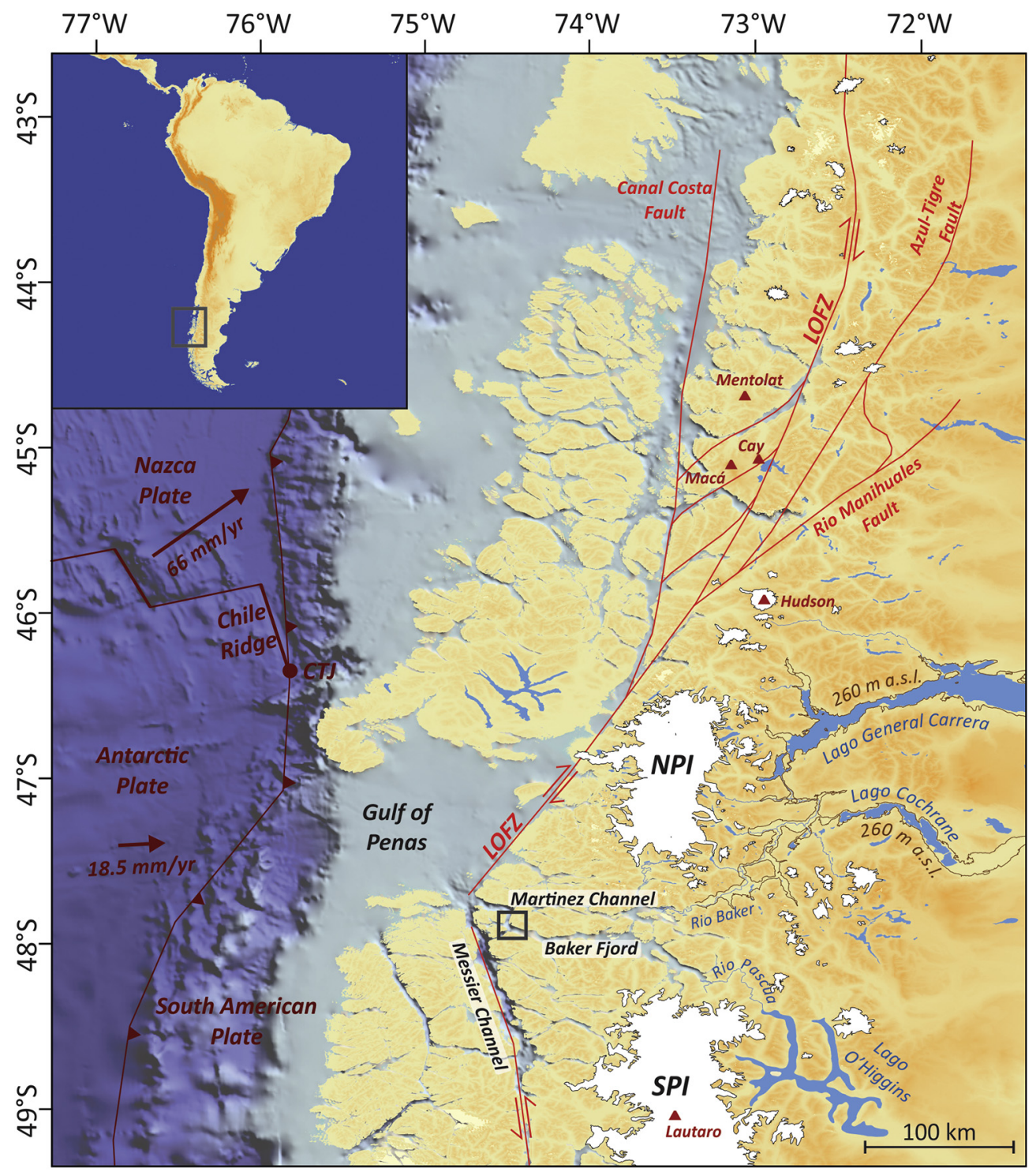

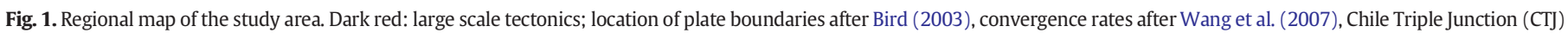

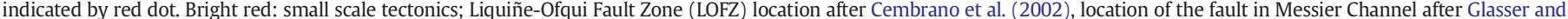

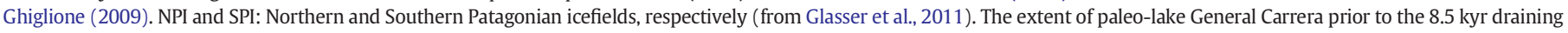
event is illustrated by the $260 \mathrm{~m}$ a.s.l. line (after Glasser et al., 2016). Volcanoes are indicated by red triangles.

triggered by earthquakes (St-Onge et al., 2012; Van Daele et al., 2013), non-seismic slope failures (Girardclos et al., 2007), or by large floods such as during the early Holocene drainage of paleo-lake General Carrera (St-Onge et al., 2004; Glasser et al., 2016). Turbidite records are therefore of key importance in paleoseismology (Goldfinger et al., 2003; St-Onge et al., 2004; Strasser et al., 2006; Wils et al., 2017; Moernaut et al., 2018) and for the reconstruction of former (mega) flood events (Russell and Knudsen, 1999; Zuffa et al., 2000; Mulder et al., 2001; St-Onge and Lajeunesse, 2007). Furthermore, these enormous subaqueous events can have catastrophic effects for fjord ecology (e.g. water circulation and methane release) but also for the surrounding environment in the form of tsunami waves (Nisbet and Piper, 1998; Girardclos et al., 2006; Fanetti et al., 2008).

The goal of this paper is to determine the exact thickness, age, mode of deposition, and triggering mechanism of the reworked deposits sampled in core MD07-3121. It does so by using a combination of geophysical data from Baker Fjord together with sedimentological and magnetic data obtained at high-resolution on sediment core MD07-3121.

\section{Regional setting}

\subsection{Fjord oceanography}

Baker Fjord is located between the Northern Patagonian Icefield (NPI, $46^{\circ} 30^{\prime} \mathrm{S}-47^{\circ} 30^{\prime} \mathrm{S}$ ) and the Southern Patagonian Icefield (SPI, $48^{\circ} 20^{\prime} \mathrm{S}-51^{\circ} 30^{\prime} \mathrm{S}$ ). Together with the Martinez Channel in the North it forms the Baker-Martinez Fjord complex (Fig. 1). The fjord complex receives fresh water input from Baker River, which drains the eastern side of the NPI, and Pascua River, which is the northward drainage of the SPI. The individual average fresh water discharge of Baker and Pascua rivers ranges between $400 \mathrm{~m}^{3} \mathrm{~s}^{-1}$ in late winter and early spring and $1500 \mathrm{~m}^{3} \mathrm{~s}^{-1}$ in summer (González et al., 2013). During GLOF events, river outflow reaches up to $2500 \mathrm{~m}^{3} \mathrm{~s}^{-1}$, discharging enormous amounts of sediment-laden water to Baker Fjord, potentially leading to flood-induced deposits (Marín et al., 2013; Worni et al., 2014).

The oceanic connection with the Gulf of Penas allows for subantarctic water to enter the fjord and create a two layer estuarine circulation 
(Pickard, 1971; Sievers and Silva, 2008; González et al., 2013). The Gulf of Penas however limits the hydrological connection between the fjord complex and the ocean as it is shallower than the fjords. Circulation of water masses is generally slow due to highly irregular bottom topography causing low oxygen levels to be present at the bottom of the deeper water column (Pantoja et al., 2011).

Suspension fallout from turbid meltwater is the dominant sedimentation process in the Chilean fjords. Sediments are usually well sorted and fine grained, and accumulation rates decrease towards the open ocean (DaSilva et al., 1997; Boyd et al., 2008; Dowdeswell and Vásquez, 2013). In Baker Fjord, DaSilva et al. (1997) observed Neoglacial ice-proximal marine deposits to be present in the inner $60 \mathrm{~km}$ of the fjord followed by ice distal sediments and non-glacial deposits near coring site MD07-3121 (Figs. 1 and 2).

\subsection{Late Quaternary climate and glaciological evolution}

The climatic patterns of southern South America are governed by the southern westerlies (Garreaud et al., 2013). On the Pacific side of the Andes, the orographic effects linked to the interplay of the westerlies with the Andes cause anomalous high precipitation levels that feed the temperate glaciers of the two icefields.

The Patagonian Ice Sheet was at its largest extent during an early Last Glacial Maximum around 28 kyr BP (Sugden et al., 2005; Glasser et al., 2008; Fogwill et al., 2015). After the Last Glacial Maximum, temperature in the region increased in phase with Antarctica (Lamy et al., 2004; Turner et al., 2005). The first step (17-15 kyr) in the Southern Hemisphere deglaciation plateaued between $15 \mathrm{kyr}$ and $12.5 \mathrm{kyr}$, i.e., during the Antarctic Cold Reversal, after which a second warming step occurred, coinciding with the Northern Hemisphere Younger Dryas (Kilian and Lamy, 2012). These higher temperatures resulted in a rapid deglaciation of the region, leading to the separation of the
Patagonian Ice Sheet in multiple icefields: the NPI, the SPI, and the Cordillera Darwin Icefield (McCulloch et al., 2000; Sugden et al., 2005, 2009). The final separation of the Patagonian Ice Sheet into the NPI and SPI in the early Holocene caused a new drainage route to open to the West. This route drained glacial paleo-lake General Carrera via the Baker-Martinez Fjord complex to the Gulf of Penas (Glasser et al., 2016).

Holocene glacier advances have been recognized in several studies around 8980-7610 cal yr BP and at the beginning of the Neoglacial at 6640-5680 cal yr BP (Douglass et al., 2005; Wenzens, 2005; Aniya, 2013). The Neoglacial consists of five periods of glacier advances according to the Aniya (2013) chronology: 5130-4430, 3850-3490, 2770-1910, 1450-750 and 350-50 cal yr BP (Nimick et al., 2016).

\subsection{Tectonic setting}

The Chile Triple Junction (CTJ) is located $300 \mathrm{~km}$ northwest of the study area (Fig. 1). At the Triple Junction, three tectonic plates meet: the Nazca and Antarctic plates, separated by the Chile Ridge, and the South American Plate, under which the two others subduct (Cande and Leslie, 1986; Lagabrielle et al., 2000). Below the South American Plate, the subduction of the Chile Ridge has led to an asthenospherefilled slab gap - or slab window - to form between the subducting Nazca and Antarctic plates (Forsythe and Nelson, 1985; Ramos and Kay, 1992; Russo et al., 2010). Furthermore, Baker Fjord lies in the Patagonian Volcanic Gap (PVG, 46-49 ${ }^{\circ}$ ), which apart from the absence of volcanic activity, is currently also characterized by only minor seismic activity at the plate interface (Ramos and Kay, 1992; Stern, 2004; Agurto-Detzel et al., 2014). The origin of the PVG has been attributed to the subduction of the Chile Ridge and thus the formation of the slab window (Ramos and Kay, 1992; Gutiérrez et al., 2005).

The Liquiñe-Ofqui Fault Zone (LOFZ) forms the dominant regional tectonic feature (Fig. 1). This dextral strike-slip fault complex accommodates

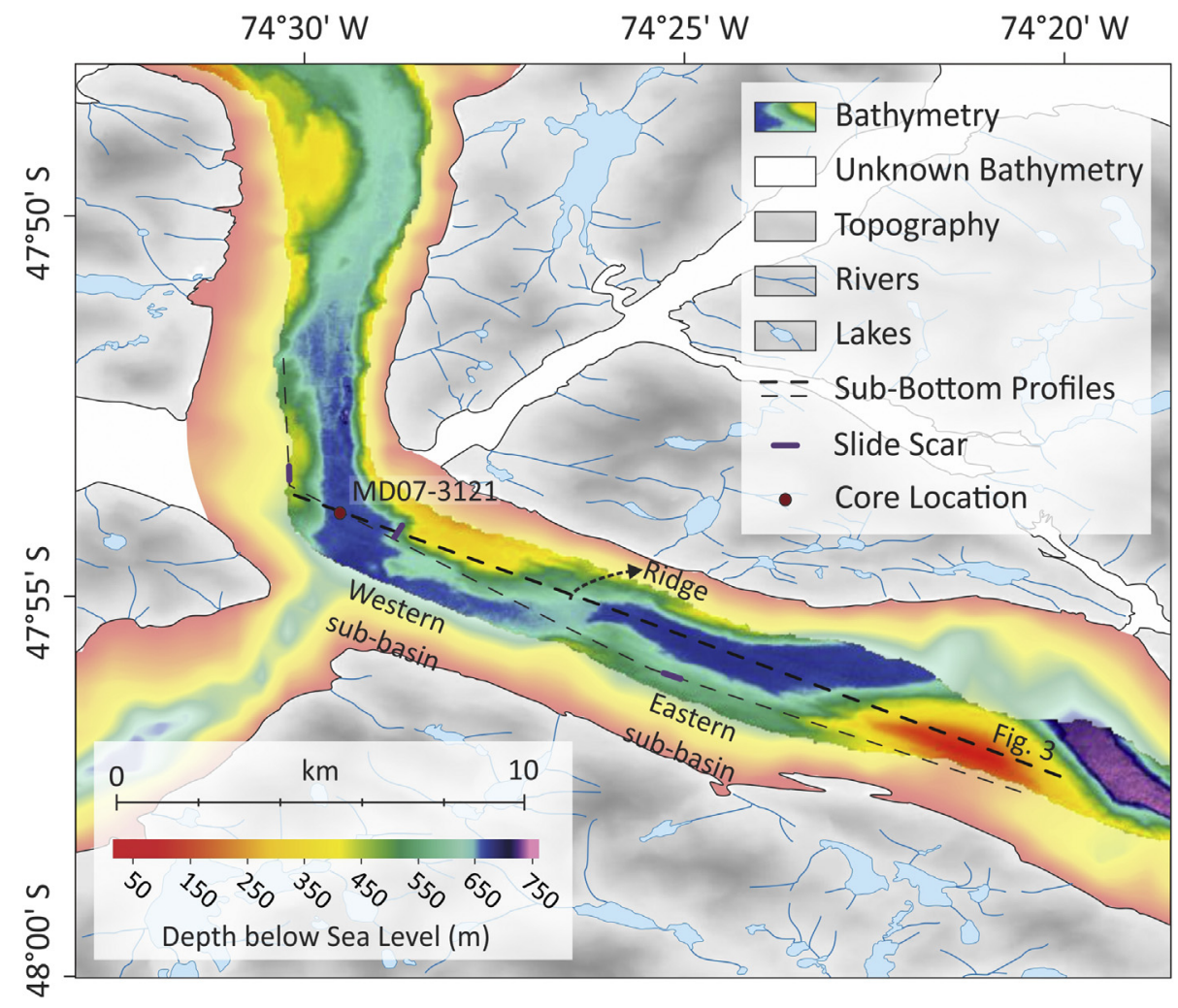

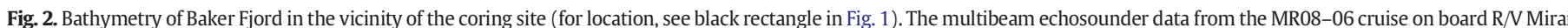

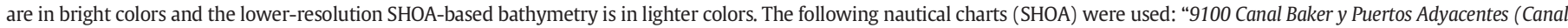

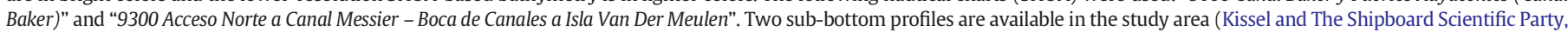
2007), of which one (thicker line) is shown in Fig. 3. 
the parallel component of the oblique convergence of the Nazca and South American plates (Cembrano et al., 1996, 2000; Diraison et al., 1998; Thomson, 2002). A secondary mechanism adding to the tectonic activity of the southern segment of the LOFZ is the subduction of the Chile Ridge under the South American Plate (Murdie et al., 1993). It has been shown by multiple authors that evidence of past tectonic activity can be found in the numerous Patagonian fjords, as different types of earthquake-triggered deposits (Chapron et al., 2006; Sepúlveda et al., 2010; St-Onge et al., 2012; Van Daele et al., 2013; Wils et al., 2017). These are however all located north of the CTJ. South of the CTJ, left lateral faults have been identified in the Messier Channel as well as in parallel channels (Ramos and Kay, 1992; Fig. 1), along which some historical seismic activity has been registered (Storchak et al., 2015). Furthermore, several faults and tectonic lineaments have been mapped in the vicinity of Baker Fjord (Forsythe and Nelson, 1985; Glasser and Ghiglione, 2009).

The seismic activity in the PVG is in general attributed to the Hudson Volcano, which lies just north of the PVG, and to the LOFZ (Agurto-Detzel et al., 2014), especially where its two main branches meet around $46^{\circ} 12^{\prime} \mathrm{S}$ (Fig. 1). The historical seismic events are mostly crustal earthquakes with hypocenter depths shallower than $15 \mathrm{~km}$ and magnitudes ranging between $M_{L} 0.5$ and 3.4 (Agurto-Detzel et al., 2014). During infrequent reactivation of the LOFZ, earthquakes can reach a magnitude around 7 , such as the $M_{W} 6.2$ April 2007 earthquake below Aysén Fjord (Lange et al., 2008; Naranjo et al., 2010; Legrand et al., 2011).

\subsection{Volcanic setting}

Although Baker Fjord is situated in the $350 \mathrm{~km}$ long PVG, there are several volcanoes nearby (Fig. 1). The southern volcanoes of the Southern Volcanic Zone (Mentolat, Cay, Macá, Hudson) lie north of Baker Fjord. Of these volcanoes, Hudson is the closest $(250 \mathrm{~km})$ and most active with known eruptions around 17,400 cal yr BP (Ho), 7750 cal yr BP (H1), 3920 cal yr BP (H2) and one of Chile's largest 20th century volcanic eruptions in 1991 CE (Naranjo and Stern, 1998; Weller et al., 2014; Perucca et al., 2015). Lautaro and Viedma volcanoes belong to the Austral Volcanic Zone and are yet to be thoroughly studied. Lautaro, the northernmost of the two $(125 \mathrm{~km}$ southeast of the study area; Fig. 1), is one of the most active stratovolcanoes of the Austral Volcanic Zone and is thought to be still active (Orihashi et al., 2004; Perucca et al., 2015). When heavy rainfall and snowmelt affect under-consolidated eruptive products such as thick ash deposits, lahars are produced (Branney and Gilbert, 1995). These dense sediment-laden flows can form large subaqueous deposits called hyperpycnites, which are often inversely graded at their base (Mulder et al., 2003).

\section{Methods}

This study makes use of the $46.33 \mathrm{~m}$ long Calypso piston-core MD07-3121 collected at the centre of Baker Fjord during the R/V Marion Dufresne 'PACHIDERME' MD/159 cruise in 2007. A $8.51 \mathrm{~m}$ long Calypso square core (CASQ) MD07-3120Cq was taken from virtually the same location providing large quantities of undisturbed sediments and a well-preserved water-sediment interface. This relatively short core was used only for gathering terrestrial remains for radiocarbon dating.

Geophysical characterization of the study area included bathymetric mapping using multibeam echosounder data from the MR08-06 cruise on board R/V Mirai (Harada and The Shipboard Scientific Party, 2008) and sub-bottom profiling from the R/V Marion Dufresne 'PACHIDERME' MD/159 cruise (Kissel and The Shipboard Scientific Party, 2007). The bathymetry was acquired with a SeaBeam 2112.004 multi-narrow beam echo sounder operating at a frequency of $12 \mathrm{kHz}$. Additionally, individual bathymetric points from nautical charts published by SHOA (Servicio Hidrográfico y Oceanográfico de la Armada de Chile; Chilean Navy Hydrographic and Oceanographic Service), were digitized and interpolated to create a complementary bathymetric map. Sub-bottom profiles were obtained with a Seafalcon 11 echosounder, which uses a central frequency of $3.75 \mathrm{kHz}$. Its large transmitted bandwidth of $1.6 \mathrm{kHz}$ results in a spatial resolution of up to $0.3 \mathrm{~m}$.

Data acquired on core MD07-3121 on board R/V Marion Dufresne include a macroscopic visual description and a set of Geotek Multi Sensor Core Logging (MSCL) physical properties measured every $2 \mathrm{~cm}$ (Kissel and The Shipboard Scientific Party, 2007). Of all the MSCL physical properties ( $\mathrm{p}$-wave velocity, Gamma density and low field magnetic susceptibility) measured on the working half of the core, only the Gamma density was used in this study.

Grain size was determined on the terrigenous fraction of 291 sediment samples of the upper $3000 \mathrm{~cm}$ of core MD07-3121, at an interval of $10 \mathrm{~cm}$ or lower (up to $2 \mathrm{~cm}$ intervals). The samples were suspended in $10 \mathrm{ml}$ of DI water and boiled with $2 \mathrm{ml} \mathrm{H}_{2} \mathrm{O}_{2}$ (35\%), $1 \mathrm{ml} \mathrm{HCl} \mathrm{(10 \% )}$ and $1 \mathrm{ml}$ of $\mathrm{NaOH}(2 \mathrm{~N})$ to remove organic matter, calcium carbonates and biogenic silica, respectively. The grain-size measurements were performed using a Malvern Mastersizer 3000 laser particle-size analyser during $12 \mathrm{~s}$. The samples were kept in suspension by a stirrer rotating at $2500 \mathrm{rpm}$. Flocculation was prevented by adding $1 \mathrm{ml}$ Calgon $\left(\left(\mathrm{NaPO}_{3}\right)_{6} ; 2 \%\right)$ prior to measurement and by using ultrasounds $(10 \%)$ during analysis. Grain-size parameters were calculated according to Folk and Ward (1957).

Volume-normalized magnetic susceptibility was measured using a Bartington MS2C $45 \mathrm{~mm}$ diameter susceptibility bridge on u-channels $(2 \times 2 \mathrm{~cm})$ at intervals of $2 \mathrm{~cm}$, achieving a resolution of ca. $4 \mathrm{~cm}$. The Anhysteretic Remanent Magnetization (ARM) was acquired with a translation speed of $1 \mathrm{~cm} \mathrm{~s}^{-1}$ in a peak alternating field of $100 \mathrm{mT}$ and a DC bias field of $50 \mu \mathrm{T}$ along the Z-axis. After its stepwise alternating field demagnetization up to $80 \mathrm{mT}$, the Isothermal Remanent Magnetization (IRM) was stepwise acquired up to $1 \mathrm{~T}$ with a $2 \mathrm{G} 1.6 \mathrm{~m}$ long pulsed solenoid. Both ARM and IRM were measured every $2 \mathrm{~cm}$ using a $2 \mathrm{G}$ model 755-R cryogenic magnetometer located in a $\mu$ metal shielded room and equipped with high resolution pick-up coils yielding a spatial resolution of $4-4.5 \mathrm{~cm}$.

Foraminifera were handpicked and counted in 2-cm-thick sediment samples at intervals varying from 10 to $60 \mathrm{~cm}$. The samples were sieved and foraminifera were counted in the $250-315 \mu \mathrm{m}$ particle-size fraction.

Organic-matter content was estimated using the loss-on-ignition ( $\mathrm{LOI}_{550}$ ) method following Heiri et al. (2001). Samples were heated and weighed after $24 \mathrm{~h}$ at $105^{\circ} \mathrm{C}$ and $4 \mathrm{~h}$ at $550{ }^{\circ} \mathrm{C}$ to calculate $\mathrm{LOI}_{550}$. A measurement was made on every other sample that was analysed for grain size. For each sample, $0.5 \mathrm{~g}$ of freeze-dried sediment was used.

Elemental $(\mathrm{C} / \mathrm{N})$ and stable isotope $\left(\delta^{13} \mathrm{C}, \delta^{15} \mathrm{~N}\right)$ composition of the bulk organic matter were determined to identify the source (terrestrial vs. marine) of sedimentary organic matter. A total of 74 freeze-dried samples of the upper $2250 \mathrm{~cm}$ of core MD07-3121 were analysed. Optimal sample weight was determined based upon the estimated total organic carbon (via $\mathrm{LOI}_{550}$ ), with a maximum of $60 \mathrm{mg}$. The sediment samples were carefully placed in silver capsules and treated with $60 \mu \mathrm{l}$ sulphurous acid $\left(\mathrm{H}_{2} \mathrm{SO}_{3} ; 5 \%\right)$ to remove any inorganic carbon. Simultaneous analysis of TOC, TN, $\delta{ }^{13} \mathrm{C}$ and $\delta^{15} \mathrm{~N}$ were carried out at the UCDavis Stable Isotope Facility on an Elementar Vario El Cube elemental analyser coupled to a PDZ Europa 20-20 isotope ratio mass spectrometer (IRMS). Samples were combusted in a copper- and tungsten (IV) oxide packed reactor at $1080^{\circ} \mathrm{C}$, after which the oxides were removed in a $650{ }^{\circ} \mathrm{C}$ reduction reactor. Before entering the IRMS, the carrier gas (He) flowed through a water trap (magnesium perchlorate) and the $\mathrm{N}_{2}$ and $\mathrm{CO}_{2}$ were separated on a Carbosieve GC column $\left(65^{\circ} \mathrm{C}, 65 \mathrm{ml} / \mathrm{min}\right)$. The standard deviation on the $\delta^{13} \mathrm{C}$ measurements is $0.04 \%$.

To obtain a core chronology, twelve broken marine shell (Mytilids) samples were radiocarbon-dated at the UC Irvine Accelerator Mass Spectrometry (AMS) facility. The conventions of Stuiver and Polach (1977) were followed for correction of the isotopic fractionation. Additionally, leaves and twigs from core MD07-3120Cq were dated using the ARTEMIS Pelletron tandem accelerator (AMS dating) at Saclay (Moreau et al., 2013). The depths of the terrestrial samples collected in MD07- 
3120Cq were projected on core MD07-3121 using the magnetic susceptibility correlations (Appendix 1). Radiocarbon dates (Table 1) were calibrated with the SHCal13 calibration curve (Hogg et al., 2013). A reservoir age correction ( $R$ ) was estimated using two sets of paired radiocarbon ages (Table 1 , samples marked with an asterisk). An age depth model for core MD07-3121 was constructed using Bacon (Blaauw and Christen, 2011).

\section{Results}

\subsection{Bathymetry}

The study area in Baker Fjord reaches water depths exceeding $675 \mathrm{~m}$ (Fig. 2). It is divided into multiple sub-basins by ridges. The ridge between the western sub-basin, where the core was taken, and the adjacent eastern sub-basin is $25-30 \mathrm{~m}$ shallower than the two sub-basins (Fig. 2). The coring site is situated in the centre of the basin, at a depth of $663 \mathrm{~m}$. The area around the coring site is relatively flat over $0.5 \mathrm{~km}^{2}$ and it is flanked by steep slopes $\left(21-42^{\circ}\right)$. Slide scars, interpreted from the sub-bottom profiles (Kissel and The Shipboard Scientific Party, 2007), are present on the flanks of the fjord (Fig. 2).

\subsection{Sub-bottom profiles}

We first describe the sedimentary package in the western sub-basin, where core MD07-3121 was taken, from bottom to top (Figs. 3 and 4; Appendices 3 and 4). The base of the sub-bottom profiles (not labelled) show a stratified seismic facies (Fig. 4). Unit $\mathbf{A}$ is identified as an erosive body as it truncates lower reflectors. Its internal acoustic signature is chaotic and transparent (Figs. 3 and 4). It is covered by unit B, another acoustically chaotic to transparent body, which has a high-amplitude yet discontinuous bottom reflection that has an erosive character. Unit C, characterized by a transparent seismic facies, again has a discontinuous bottom reflector, but does not show truncation. The top of the unit holds two continuous, parallel reflectors. Unit $\mathbf{D}$ is characterized by a continuously stratified acoustic facies, and has a draping geometry, i.e. following the underlying topography with a constant thickness. While the steep $\left(21-42^{\circ}\right)$ slopes that surround the basin floor bare no to little sediments, the platform ( $350 \mathrm{~m}$ deep) to the southeast of the sub-basin does have a sediment cover with a thickness up to $70 \mathrm{~ms}$ TWT ( $\sim 52 \mathrm{~m}$; inset in Fig. 3 ). At the western side of this platform, the sediment cover terminates with a vertical wall of $100 \mathrm{~ms}$ TWT $(\sim 70 \mathrm{~m})$ that can be interpreted as a slide scar (Schnellmann et al., 2005; L'Heureux et al., 2014; Praet et al., 2017). Similar scars are visible at several other locations in the fjord (Fig. 2).
East of the ridge, in the eastern sub-basin, the sedimentary sequence is similar to that in the western sub-basin, allowing a one-to-one correlation of the seismic units between the basins, apart from unit $\mathbf{A}$, which is not present on the eastern side of the ridge (Fig. 3). Unit B has a chaotic to transparent seismic facies and has strong relief in the eastern sub-basin (Fig. 4). The unit is thicker at the foot of the slope, where it is highly erosional, than in the centre of the sub-basin. In the thicker part of unit $\mathbf{C}$, at the southeastern end of this sub-basin, discontinuous internal reflectors are present (Fig. 4). The unit shows more relief in this sub-basin than in the western one and it wedges out towards the southeast end of the sub-basin. Similar to the western sub-basin, the top consists of two continuous, parallel reflectors. The thickness and seismic facies of unit $\mathbf{D}$ is very similar to that in the western sub-basin.

\subsection{Sedimentological and magnetic analyses}

The sediments below $3250 \mathrm{~cm}$ in core MD07-3121 show high variability of ARM/IRM and low and moderately variable magnetic susceptibility values (below $1250 \times 10^{-6} \mathrm{SI}$; Fig. 4). Three clear magnetic susceptibility peaks are present at 4009, 3667 and $3559 \mathrm{~cm}$, and a smaller peak at $3353 \mathrm{~cm}$ (Fig. 4). The sedimentological and magnetic data of the upper $3250 \mathrm{~cm}$ of core MD07-3121 allow subdividing the core into 5 zones (roman numbers; Figs. 4 and 5).

The sediments of zone I (3245-2669 cm) are described as homogenous greyish olive mud with some sand layers. The base of zone I is marked by a sand layer and a sudden increase in density and magnetic susceptibility (Fig. 4). The lower part of the zone up until $2967 \mathrm{~cm}$ has high and variable magnetic susceptibility values (Fig. 4). In the upper part of zone I, no foraminifera are present and lower magnetic susceptibility values occur with a sudden decrease at $2783 \mathrm{~cm}$ (Fig. 5). LOI $_{550}$ shows a gradual increasing trend in the upper $300 \mathrm{~cm}$ of this zone. The sediments of zone I are poorly sorted below $2783 \mathrm{~cm}$, especially below $2967 \mathrm{~cm}$ which is enriched in coarse particles (Fig. 5). Finer sediments with a higher degree of sorting follow in the upper part of the zone, above $2783 \mathrm{~cm}\left(\mathrm{D}_{10}\right.$ : 1.55 to $\mathrm{D}_{90}: 15.62 \mu \mathrm{m}$; Fig. 5).

Zone II $(2669-1533 \mathrm{~cm})$ is composed of greyish olive mud with sand layers at its base (Fig. 5), and it is characterized by fluctuations in all parameters. The base of the zone is defined by an increased grain size and a sharp 6-cm-thick magnetic susceptibility peak, which correspond to lower $\mathrm{LOI}_{550}$ values (Fig. 5). The lower $270 \mathrm{~cm}$ of the zone contains thin $(2-6 \mathrm{~cm})$ coarse grained layers. Foraminifera occur in variable concentrations throughout the zone.

Zone IIIa $(1533-800 \mathrm{~cm})$ is composed of homogenous grey mud with occasional thin silt layers between 1450 and $1300 \mathrm{~cm}$ (Fig. 5). The base of the zone is marked by a peak in both grain size

Table 1

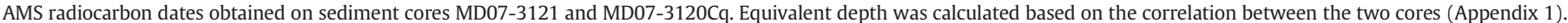
Calibrated age ranges were calculated using the SHCal13 calibration curve (Hogg et al., 2013). The asterisks $\left(^{*}\right)$ indicate samples used for calculation of the reservoir effect.

\begin{tabular}{|c|c|c|c|c|c|c|c|c|}
\hline Core MD07- & Lab code & $\begin{array}{l}\text { Sample depth } \\
(\mathrm{cm})\end{array}$ & $\begin{array}{l}\text { Equivalent depth in } \\
\text { MD07-3121 }(\mathrm{cm})\end{array}$ & Material & Amount & $\delta^{13} \mathrm{C}(\%)$ & ${ }^{14} \mathrm{C}$ age $(\mathrm{yr} \pm 1 \sigma)$ & $\begin{array}{l}2 \sigma \text { calibrated age } \\
\text { range (cal yr BP) }\end{array}$ \\
\hline 3121 & UCI - 151157 & $391^{*}$ & - & Shell & $0.18 \mathrm{mgC}$ & - & $2660 \pm 20$ & $2672-2341$ \\
\hline 3121 & UCI - 151158 & $437^{*}$ & - & Shell & $0.23 \mathrm{mgC}$ & - & $2895 \pm 20$ & $2775-2721$ \\
\hline 3121 & UCI - 151159 & 670 & - & Shell & - & - & $4515 \pm 20$ & $4857-4650$ \\
\hline 3121 & UCI - 151160 & 1616 & - & Shell & - & - & $8775 \pm 25$ & $9536-9468$ \\
\hline 3121 & UCI - 151161 & 1708 & - & Shell & - & - & $8580 \pm 25$ & 9429-9141 \\
\hline 3121 & UCI - 151162 & 1783 & - & Shell & - & - & $10,030 \pm 25$ & $11,235-11,138$ \\
\hline 3121 & UCI - 151163 & 1976 & - & Shell & - & - & $9490 \pm 25$ & $10,490-10,254$ \\
\hline 3121 & UCI - 151164 & 2051 & - & Shell & - & - & $13,185 \pm 30$ & $15,605-15,230$ \\
\hline 3121 & UCI - 151165 & 2163 & - & Shell & - & - & $6120 \pm 25$ & $6738-6555$ \\
\hline 3121 & UCI - 151166 & 2364 & - & Shell & - & - & $5290 \pm 25$ & $5891-5652$ \\
\hline 3121 & UCI - 151167 & 2441 & - & Shell & - & - & $12,470 \pm 30$ & $14,199-13,958$ \\
\hline 3121 & UCI - 151168 & 2580 & - & Shell & $0.26 \mathrm{mgC}$ & - & $7560 \pm 25$ & 8168-8017 \\
\hline $3120 \mathrm{Cq}$ & SacA44940 & 222 & 185 & Leaf & $0.44 \mathrm{mgC}$ & -32.4 & $1175 \pm 30$ & 1089-958 \\
\hline $3120 \mathrm{Cq}$ & SacA44941 & 269 & 232 & Leaf & $1.11 \mathrm{mgC}$ & -28.1 & $1355 \pm 30$ & 1293-1183 \\
\hline $3120 \mathrm{Cq}$ & SacA44942 & 399 & $362^{*}$ & Leaf & $0.36 \mathrm{mgC}$ & -37.0 & $2210 \pm 30$ & 2308-2088 \\
\hline $3120 \mathrm{Cq}$ & SacA44943 & 440 & $403^{*}$ & Twig & $0.32 \mathrm{mgC}$ & -36.2 & $2490 \pm 40$ & 2705-2359 \\
\hline
\end{tabular}




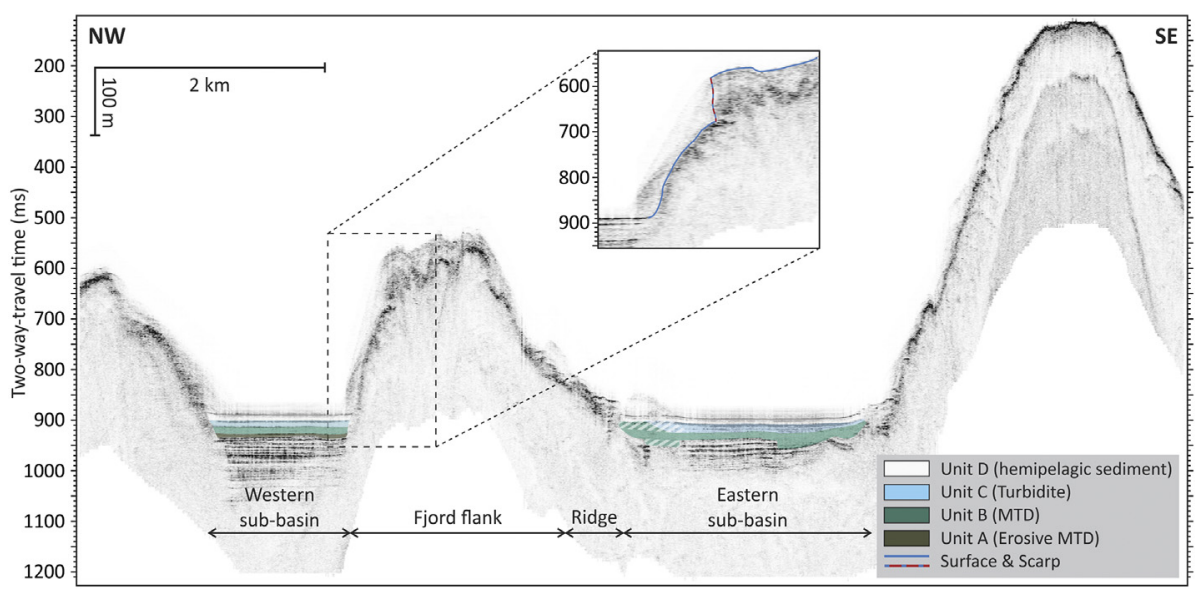

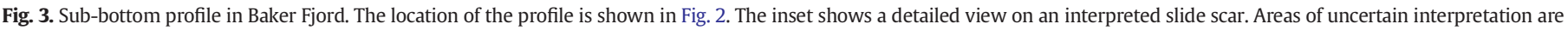
indicated by the hatched areas. See Fig. 4 for a detailed view of the two sub-basins. The uninterpreted profile is presented in Appendix 3.

(up to $\sim 74 \mu \mathrm{m}$ ) and magnetic susceptibility. Both parameters gradually decrease upwards throughout zone IIla as opposed to the shortlived basal grain size and magnetic susceptibility peak of zone II (Fig. 5). The zone displays a general fining upward trend, which is particularly pronounced in the lower $200 \mathrm{~cm}$. From the base of the zone up to $1150 \mathrm{~cm}$, and especially between 1430 and $1300 \mathrm{~cm}$, the decreasing trend is stepwise and fluctuates, i.e. coarser peaks occur (e.g. at $1330 \mathrm{~cm}$ and $1150 \mathrm{~cm}$ ). The grain-size distribution plot (Fig. 5) shows that most of zone IIIa has a fine mode similar to that of zone II but with an extra, larger grain-size mode at the base. An increase in $\mathrm{LOI}_{550}$ is observed throughout the zone. The ratio of laboratoryimposed remanences, ARM/IRM - a parameter inversely correlated to the magnetic grain size - shows a sudden and relatively small decrease and subsequent gradual increase at the bottom of zone IIIa, after which it remains steady up to $1120 \mathrm{~cm}$. Above, a gradual increase of the ARM/ IRM ratio occurs. Apart from the lower three samples which contains some Globobulimina affinis, the zone lacks foraminifera. Zone IIIb $(800-745 \mathrm{~cm})$ is defined by the lowest grain-size values of the entire core (ranging between $\mathrm{D}_{10}: 1.25$ to $\mathrm{D}_{90}: 17.74 \mu \mathrm{m}$ ) and it consists of homogenous grey mud (Fig. 5). It also corresponds to the re-appearance of significant amounts of foraminifera, predominantly of the species Melonis barleeanus. In terms of $\mathrm{LOI}_{550}$, the zone forms a transition from ca. $5 \%$ in zone IIIa to ca. $7 \%$ in zone IV above. Magnetic susceptibility is constant and very low, while the ARM/IRM indicates very fine grains with a slight fining trend towards the top.

The upper $745 \mathrm{~cm}$ of the core, zone IV, is composed of grey to greyish olive homogenous mud, and it shows moderate and variable $\mathrm{LOI}_{550}$ values accompanied by a slight increase in magnetic susceptibility. The base of the zone is marked by an ARM/IRM peak and cm-scale bioturbation (Appendix 2). The ARM/IRM ratio increases significantly between 235 and $195 \mathrm{~cm}$. The total foraminifera abundance suddenly reaches a maximum at 140 $\mathrm{cm}$ depth, but the fossils are absent between 60 and $40 \mathrm{~cm}$.

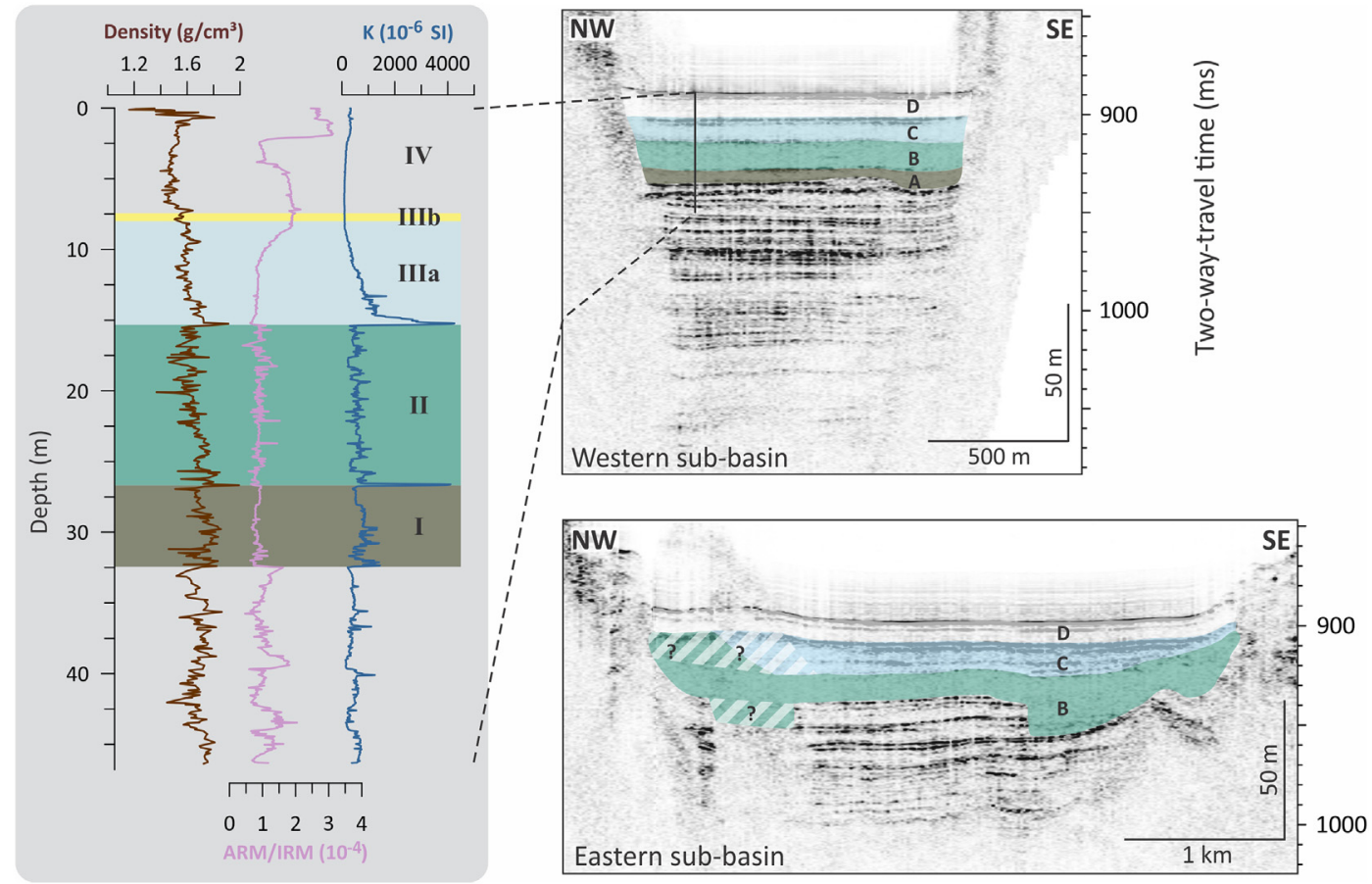

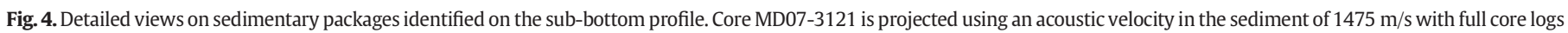
of density, ARM/IRM and magnetic susceptibility. Areas of uncertain interpretation are indicated by the hatched pattern. The uninterpreted profiles are presented in Appendix 4. 


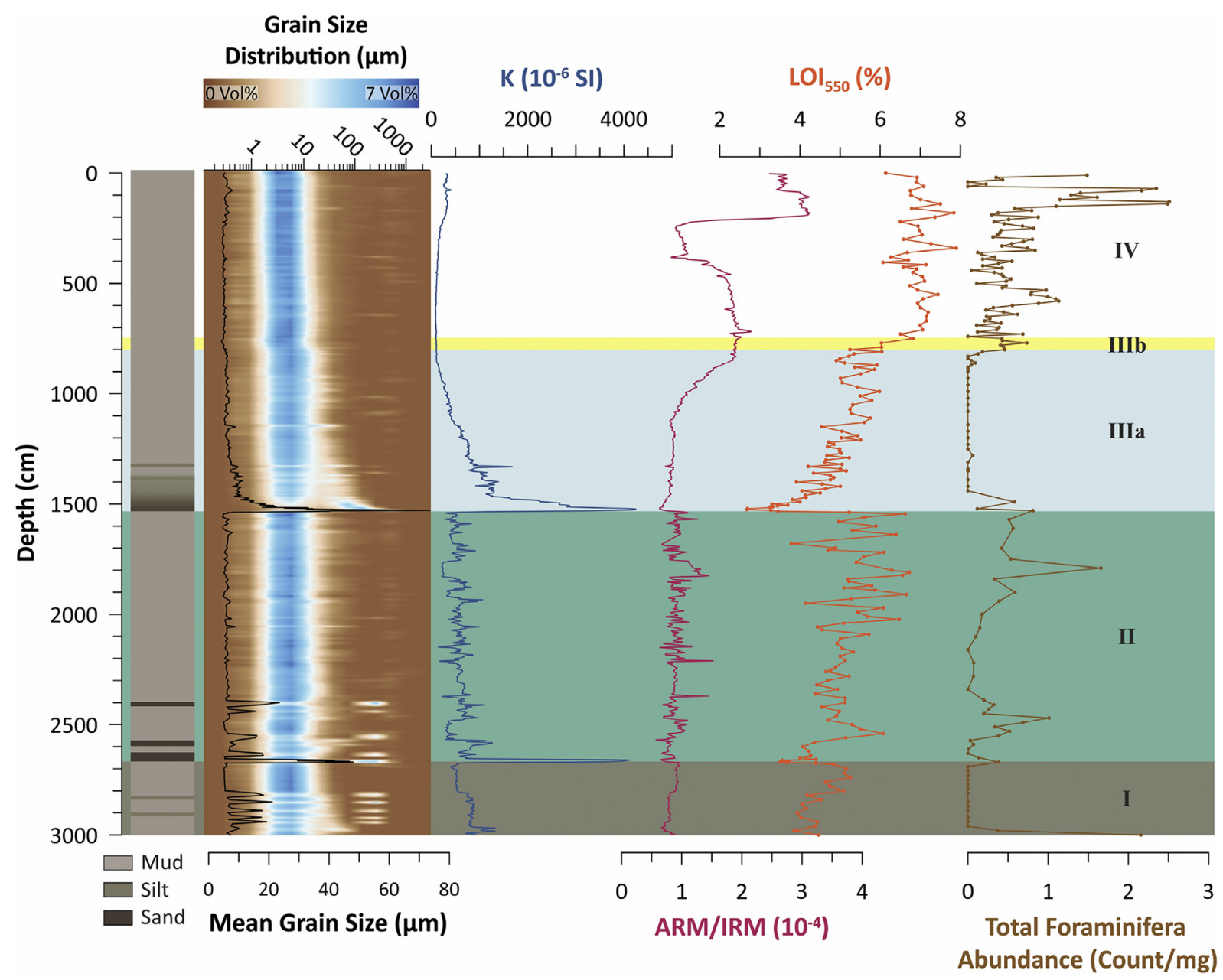

Fig. 5. Selected sedimentological and magnetic parameters together with a sedimentary log of the top $3000 \mathrm{~cm}$ of core MD07-3121.

\subsection{Bulk organic geochemistry}

The total organic carbon (TOC) is in general very low (under 2\%; Fig. 6). The highest variability is present in zone II, where it ranges between 0.7 and $1.6 \%$. Zone IIIa holds the lowest values, but the TOC gradually increases upwards within the zone. Zone IIIb forms a transition to higher values around $1.6 \%$ in zone IV (Fig. 6). Apart from a few exceptions, atomic $\mathrm{C} / \mathrm{N}$ values range from 7 to 10 throughout the entire core, and most of the samples have $\delta^{13} \mathrm{C}$ values varying around $21 \%$, representing marine particulate organic carbon (POC; Lamb et al. (2006); Fig. 6). Only one sample $(1840 \mathrm{~cm})$ has a $\delta^{13} \mathrm{C}$ value below -22 and seven samples plot above $-18 \%$. These 7 samples also show a higher $\mathrm{C} / \mathrm{N}$ ratio $(>10)$. They include two samples from zone II $(1638$ and $1970 \mathrm{~cm}$ ), and the five lowermost samples from zone IIIa, which also have the lowest TOC of the entire core. At the base of zone IIIa, both the $\mathrm{C} / \mathrm{N}$ ratio and $\delta^{13} \mathrm{C}$ decrease upwards.

\subsection{Chronology}

According to the correlation between MD07-3120Cq and MD073121 (Appendix 1), core MD07-3121 misses the top $37 \mathrm{~cm}$ of the sediment record. The surface of core MD07-3121 is therefore older than the year of core collection (2007). A reservoir effect of $240 \pm 5 \mathrm{yr}$ was estimated based upon the difference between the linear regression of two terrestrial samples and that of two marine samples (Table 1). This was applied to all the marine shell samples, assuming the reservoir effect remained relatively constant through time. The radiocarbon ages obtained on the shell fragments below $1535 \mathrm{~cm}$ show an inconsistent pattern. Due to the likely reworked origin of the sediment unit in which these ages were obtained, they are not accounted for in the age-depth model. In total, seven radiocarbon ages and the core collection age $(2007 \mathrm{CE}$ at $-37 \mathrm{~cm}$ ) are included in the age-depth model. The model holds rather stable accumulation rates above $437 \mathrm{~cm}$ ranging between 1.6 and $2.5 \mathrm{~mm} / \mathrm{yr}$. The lower section of the model shows lower accumulation rates close to $1 \mathrm{~mm} / \mathrm{yr}$. The top of zone IIIb $(745 \mathrm{~cm})$ has a $95 \%$ certainty age range of 5513-5211 cal yr BP.

\section{Discussion}

\subsection{Core to seismics correlation}

Core MD07-3121 was projected on the sub-bottom profile using an acoustic velocity of $1475 \mathrm{~m} / \mathrm{s}$ in order to correlate the geophysical features with the density and magnetic susceptibility (Fig. 4). The acoustic velocity was calculated based on the correlation of the base of unit A ( $44 \mathrm{~ms}$ TWT bsf) with abrupt changes in physical properties in the core at $3282 \mathrm{~cm}$ bsf (corresponding to $3245 \mathrm{~cm}$ in core MD07-3121; Appendix 1; Fig. 4) and is in agreement with the MSCL P-wave velocity (Kissel and The Shipboard Scientific Party, 2007). The projection shows that the core covers all of the seismic units described above (Fig. 4).

Seismic units A, B, C, and D can be correlated to sedimentary zones I, II, III ( $\mathrm{a}$ and $\mathrm{b}$ ) and IV, respectively (Fig. 4). The boundaries between the sedimentary zones are indeed characterized by marked changes in density, which affect the acoustic impedance, and thus result in the 


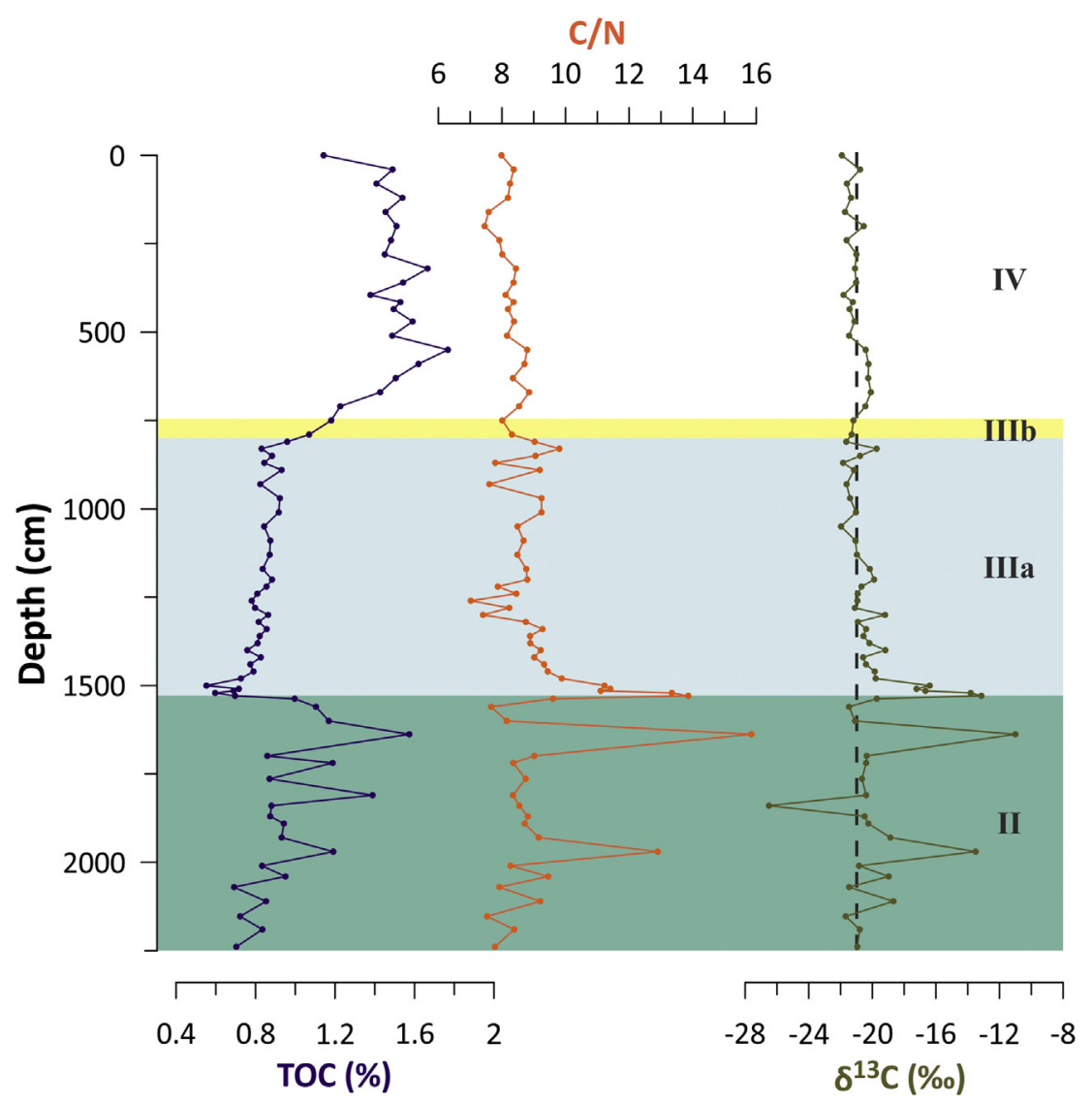

Fig. 6. Selected organic geochemistry parameters. The dashed line shows the $-21 \%$ value representing a typical marine POC signature (Lamb et al., 2006).

high-amplitude seismic reflections that denote the boundaries between the seismic units. Also, the homogenous sedimentary facies of zone III ( $\mathrm{a}$ and $\mathrm{b}$ ) is in good agreement with the acoustic transparency of unit $\mathrm{C}$ and thus confirms the core-to-seismic correlation.

\subsection{Depositional processes}

The available data shows that two events created the different sediment units in core MD07-3121, each of which will be described in this section. The lowermost deposit observed in this study is unit $\mathbf{A}$ (Zone I). It is interpreted to be a highly cohesive mass transport deposit (MTD). The sediments likely primarily originated from the eastern side of the western basin, as evidenced by deeper erosion into the underlying sediments (Fig. 4). It reached the sub-basin with energy high enough to erode and rework significant amounts of sediment. The finer and better sorted sediments at the top (from $2967 \mathrm{~cm}$ to the top of the zone) may be interpreted as a turbidite following the cohesive MTD (Fig. 5). The fine-grained mud tail ( $D_{10}: 1.55$ to $\left.D_{90}: 15.62 \mu \mathrm{m}\right)$ of the latter needs a sufficient amount of time (days to even months) to settle (Baas et al., 2000; McHugh et al., 2011; Van Daele et al., 2017). This implies that the event that triggered unit A (Zone I) is independent of the event that created the overlying deposits discussed below. Due to the erosive character of unit $\mathrm{B}$, it is difficult to estimate the amount of time between the deposition of unit $\mathrm{A}$ and the following deposits (Units B and C).

The deposits of unit B (Zone II) are interpreted to be an MTD (Figs. 3 and 4). The 6-cm-thick sand layer at the base of zone II does likely not occur throughout the entire sub-basin due to small topographic effects, causing the discontinuous character of the basal reflector. The chaotic/ transparent seismic facies, in combination with the sharp undulating basal reflector are key characteristics to recognize an MTD in an acoustic sub-bottom profile (Jackson, 2011). The deposits follow the lower topography, which is a typical criterion for a flow-like deposit, but it does not show a clear turbidite signature, i.e., no gradual fining upward (Mulder and Alexander, 2001) (Fig. 5). Instead, all the sedimentological and magnetic parameters show a high degree of variability (Fig. 5), as well as the radiocarbon dates, which fluctuate between 15,605-15,230 and 5891-5652 cal yr BP, with no consistent pattern (Fig. 7). All the above arguments lead to the interpretation that these deposits can be classified as a cohesive mud-rich debris flow according to the classification of Mulder and Alexander (2001). In a cohesive mud flow, there is little to no sediment sorting and all sediment is mixed randomly, explaining the highly variable patterns seen in all sedimentological parameters as well as the scattering of the radiocarbon ages (Figs. 5 and 7).

Unit C (Zone IIIa) has a clear fining upward trend over $733 \mathrm{~cm}$ in core MD07-3121 (Fig. 5), which provides strong evidence that zone IIIa corresponds to a turbidite (Stacey and Bowen, 1988; Mulder and Alexander, 2001). This is a non-cohesive flow deposit where sorting is controlled by the grain size and density of the particles. This explains why the magnetic grains, having a higher density, settle earlier than the siliciclastic grains of the same size (Fig. 5). The fining upward trend is most pronounced at the base of the turbidite, indicating that the turbidity flow was at its maximal energy at the head of the flow after which its energy decreases (waning). Given the thickness of this deposit, it is appropriately called a megaturbidite (Bouma, 1987).

The grain-size fluctuations in the sandy mud above the sandy base may indicate the presence of seiche waves during deposition (Fig. 5). The grain-size data of this megaturbidite is comparable to that of other event deposits where seiching occurred (Mulder et al., 2009; Campos et al., 2013, 2014). The seiche waves could have originated from either the submarine slope failure (Schnellmann et al., 2002), directly by the seismic waves of an earthquake (Chapron et al., 1999) or a combination of the two. Due to the size of the MTDs, at least part 


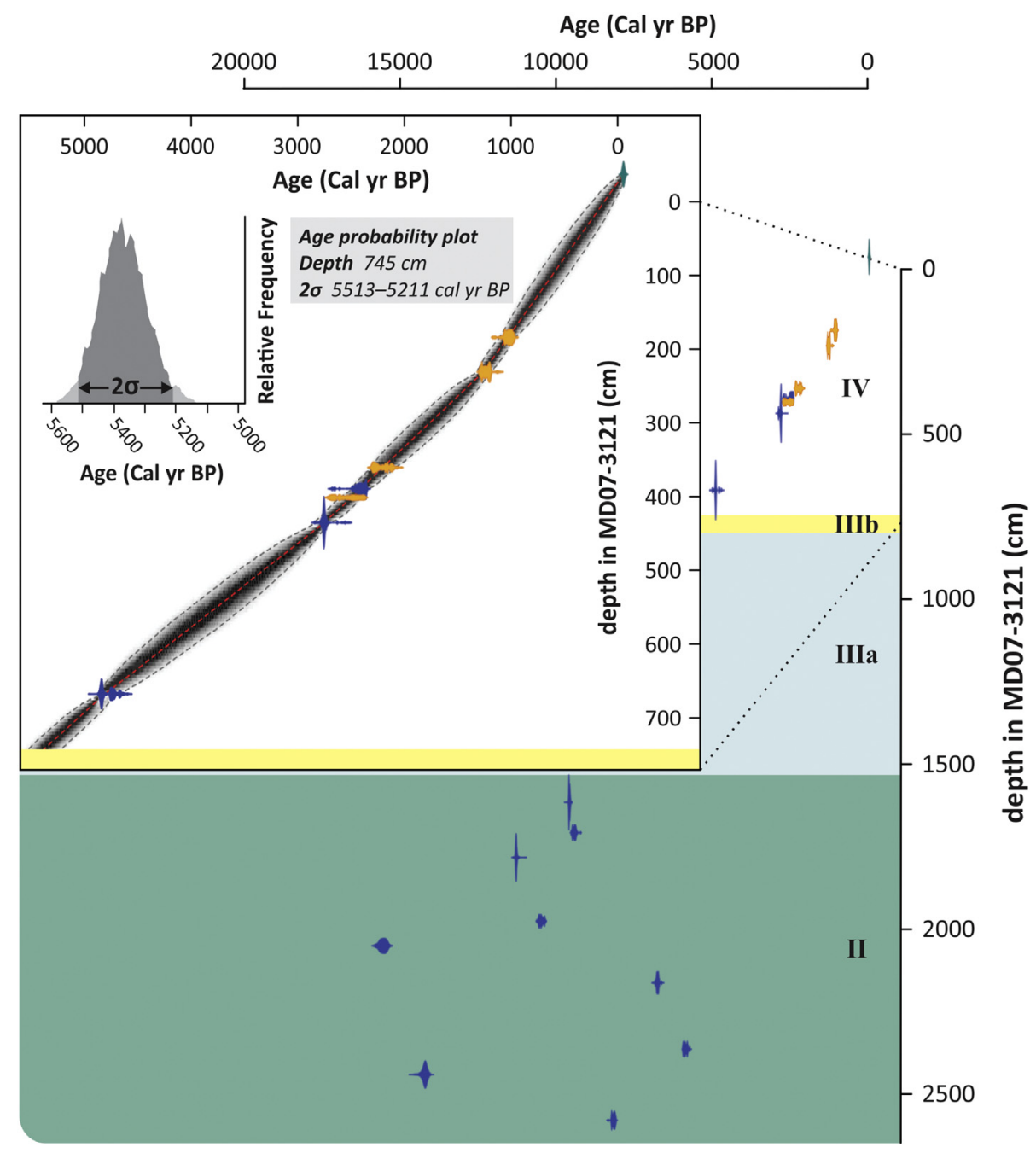

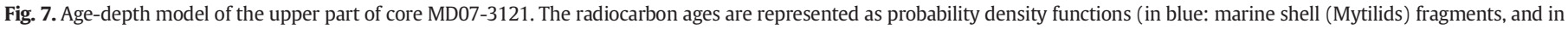
orange: terrestrial remains). The age probability distribution of the sediment deposited immediately above zone IIIb (745 cm) is also indicated.

of the seiche must have been caused by the submarine slope failures. The confined basin in the Baker Fjord enables the existence of the seiche waves, while the deep bathymetry and water stratification facilitates their development (McGarr, 1965; Sievers and Silva, 2008; Mulder et al., 2009). The discontinuity of the basal reflector of unit C (Fig. 4) is attributed to the interaction of the thin coarse-grained basal layer with small basin topography differences.

The turbidity flow (zone IIIa) gradually transitions upward into zone IIIb (Fig. 5). This finer, more homogenous deposit, is interpreted as a clay cap, i.e., the upper limit of the megaturbidite, formed by fallout of the finest suspended sediment (clay to fine silt). This interpretation is confirmed by the high abundance of foraminifera shells in this zone, especially compared to underlying zone IIIa (Fig. 5). This feature is likely related to the high floating capacity of certain foraminifera species (e.g. Melonis barleeanus), caused by their low overall density which comes from their lightweight, thin walls and empty chambers. Those do therefore not occur in the turbidity flow itself (zone IIIa), but they settled together with the finest sediments. The presence of foraminifera at the base of zone IIIa could be explained by heavier more thick-walled species (e.g. Globobulimina affinis), similar to sorting processes shown in earthquake triggered turbidites offshore Japan (Usami et al., 2017). The sediment plume at the origin of zone IIIb is estimated to be deposited in an order of weeks to months in contrast to the turbidity flow, expected to be deposited in the order of minutes to hours (Baas et al., 2000; McHugh et al., 2011; Van Daele et al., 2015).

The sediment of zone IV is not related to the event deposit. It represents post-event continuous sedimentation, as suggested by the presence of bioturbation (Appendix 2) and the self-consistent pattern of the radiocarbon ages (Fig. 7). The sudden increase of the ARM/IRM ratio between $235 \mathrm{~cm}$ and $195 \mathrm{~cm}$ (Fig. 5) is attributed to postdepositional dissolution processes such as described by Zheng et al. (2010). The large variations in foraminifera abundance could reflect changes in the fjord's productivity or post depositional dissolution processes.

The equal thickness of unit $D$ in both sub-basins suggests that the sedimentary packages of units B-C in both sub-basins (Fig. 3) are simultaneously deposited, assuming similar sedimentation rates in the two sub-basins. Although the units can be correlated, there are some discrepancies between the two sub-basins. Unit A is missing in the eastern sub-basin and unit B shows a stronger erosive character. The turbidite in the eastern sub-basin (Unit C) shows internal reflectors following the topography (Fig. 4). These may be attributed to strong flow movements influenced by topography in the confined space of this basin that introduces a certain sorting of the sediment.

When combined, the geophysical and sedimentological data suggest that units $B$ and $C$ represent consecutive event deposits likely triggered by one single event and unit A represents a separate event. Although it is 
not possible to calculate the exact volume of the reworked deposits (units B-C), the combined thickness of units B-C in the western subbasin $(19.24 \mathrm{~m})$ and the associated erosive features point towards a highly energetic triggering mechanism. The thickness of the deposits can be explained partially by the confined topography of the subbasins, however a vast amount of available sediments is necessary as well. As the turbidity flow is trapped within the confined sub-basin, complex depositional processes such as ponding occur (Sinclair and Tomasso, 2002; Patacci et al., 2015). Another consequence of these fjord topography - turbidity current interaction processes is the above discussed seiching.

\subsection{Timing and provenance}

According to the age depth model (Fig. 7) the event dates back to the late mid-Holocene (5513-5211 cal yr BP). This is further supported by the youngest age within the MTD immediately below the turbidite (Unit B) giving a maximum age limit of 5891-5652 cal yr BP (Table 1). The shell must have been deposited prior to the event to be incorporated in the MTD below the megaturbidite.

Baker Fjord is an area susceptible to GLOFs (Casassa et al., 2010; Dussaillant et al., 2010). A catastrophic event as large as the early Holocene GLOF that drained paleo-lake General Carrera through Baker Fjord (Glasser et al., 2016) could explain the thickness of the deposits. The age of the studied event deposits is however not in agreement with the $8.5 \mathrm{kyr}$ massive event described by Glasser et al. (2016), after which the Northern and Southern Patagonian Ice Sheet were permanently separated. A mid-Holocene GLOF origin is possible as the age range (5513-5211 cal yr BP) corresponds to an interglacial period (Aniya, 2013). Nonetheless, there is no geomorphological evidence for a proglacial lake that could have burst at that time. In addition, the only two rivers large enough to generate a GLOF into Baker Fjord are Baker and Pascua rivers, both of which discharge into the fjord at its eastern end (Fig. 1). A hyperpycnal flow coming from the East would get trapped in the $1060 \mathrm{~m}$ deep sub-basin $\left(73.8^{\circ} \mathrm{W}\right)$ that lies on its path to our study area, (Piret et al., 2017), rendering this hypothesis impossible. The presence of sand grains in the turbidite also refutes a GLOF travelling as a hypopycnal flow. Furthermore, if a GLOF had caused the megaturbidite and related deposits in Baker Fjord, it would have an extrabasinal origin (Zavala and Arcuri, 2016). However, the provenance of the sediment is dominantly marine, as derived from the bulk geochemical composition of the sedimentary organic matter preserved in zones II, IIla and IIIb (Fig. 6). Although part of the sediment may have been entrained from the fjord bottom by the turbidity current, this process would not completely erase the original provenance of the deposit, especially since erosion by large flood turbidity currents only occurs within a few kilometres of river mouths (Mulder et al., 1998), where, in Baker Fjord, the sedimentary organic matter is still entirely terrestrial (Rebolledo et al., submitted for publication). The deposits are therefore intrabasinal, i.e. the sediments originated from within the fjord.

An exception to the typically marine bulk geochemical values in zone III are the five samples with elevated $\delta^{13} \mathrm{C}$ values at the base of the turbidite, which are systematically associated to coarser grain sizes (Fig. 6). Similar values were measured in two samples of the underlying MTD (zone II). Based on their $\mathrm{C} / \mathrm{N}$ and $\delta^{13} \mathrm{C}$ values, we interpret these samples as enriched in marine macrophytes or algae, since similar values were measured by Mayr et al. (2011) on brown algae in Comau Fjord (Chile, $42^{\circ} \mathrm{S}$ ). These observations suggest that the origin of the sediment composing the turbidite is similar to the MTD sediments, the only difference being the preferential deposition of organic remains of macrophytic or algal origin within the coarse fraction of the sediment at the base of the turbidite. The presence of samples containing organic matter of algal or macrophytic origin in zones II and III suggests that these zones are composed of sediment previously deposited at shallower depths. This is in clear contrast with the sediments of zone
IV, for which no elevated $\delta^{13} \mathrm{C}$ and $\mathrm{C} / \mathrm{N}$ values were observed, indicating hemipelagic sedimentation.

The presence of slide scars additionally supports a marine origin of the sediments. There are three observed slide scars in only two subbottom profiles indicative of the possible presence of more similar erosive features (Fig. 2). However, it is not possible to link these features directly to the studied event with absolute certainty, although the large volume of the event related deposits would suggest so.

The slope-failure origin is further supported by the sedimentological information obtained on core MD07-3121 (Fig. 5). The Baker Fjord megaturbidite is normally graded, especially at the base, which confirms the intrabasinal origin (Kneller and Buckee, 2000). In contrast, extrabasinal turbidity flows often have an inverse velocity profile with a faster tail than head of the flow, leading to inversely graded beds at the base of the deposit (Kassem and Imran, 2001).

Finally, our findings on the origin of the sediments discussed in this study are in agreement with the available scientific literature. Based on seismic profiles, DaSilva et al. (1997) had indeed suggested deposition by debris flows from the fjord flank and reworked by tidal currents.

The presence of coeval turbidites (Unit C) in the two sub-basins, and erosional MTDs (Unit B) on both sides of the ridge (Figs. 3 and 4), indicate synchronous slope failures (Schnellmann et al., 2002; Van Daele et al., 2014). Together with the intrabasinal origin of the sediments, this argument provides evidence for seismic triggering and refutes a spontaneous slope failure, which would not have affected the two independent basins. In other Chilean fjords (e.g. Reloncaví Fjord, Aysén Fjord), such thinner seismo-turbidites have already been described (St-Onge et al., 2012; Wils et al., 2017). However, this study shows the first evidence of a seismically-triggered megaturbidite in a fjord south of the CTJ.

\subsection{Triggering earthquake}

For lake sediments, there seems to be a consensus that macroseismic intensities must reach or exceed VI to trigger subaquatic slope failures, as similar threshold intensities have been shown for lakes in a wide variety of settings around the world (Monecke et al., 2004; Moernaut et al., 2014; Van Daele et al., 2015; Wilhelm et al., 2016). Due to the limited number of studies on earthquake-triggered deposits in fjords, it is unknown if this relation can be extrapolated to fjord sediments. Even though the size of the megaturbidite and associated MTD described in this study is very large compared to the average fjord seismo-turbidite (e.g. St-Onge et al., 2012; Van Daele et al., 2013, 2014; Haeussler et al., 2014), the volume of the deposit may not directly reflect the intensity of the triggering seismic event. Considering the large influence of type and rate of background sedimentation, interpretations on quantitative paleoseismology derived from subaqueous sedimentary records need to be taken cautiously (Moernaut et al., 2007; Bertrand et al., 2008; Leyton et al., 2009; Wilhelm et al., 2016). Hence, it is possible that due to the low seismicity south of the CTJ (Hayes et al., 2015), sediments accumulated into very thick sequences before slope failures were triggered, causing the observed voluminous deposits. As such, an earthquake causing relatively low macroseismic intensities (i.e., VI) in the study area could have triggered these massive deposits. As the study area is located in a subduction zone, three possible earthquake sources are recognized: (1) a megathrust earthquake originating from the plate interface, (2) an intraslab earthquake generated by slab pull and (3) a crustal earthquake:

- (1) Megathrust earthquakes can cause macroseismic intensities of VI or more in large areas (Astroza et al., 2012) and megaturbidites found in Reloncaví Fjord $\left(41^{\circ} 40^{\prime} \mathrm{S}\right)$ have been attributed to such earthquakes on the Valdivia segment (north of the CTJ; St-Onge et al., 2012). Likewise, a single Holocene turbidite in Aysén Fjord was interpreted as having a megathrust earthquake origin (Wils et al., 2017). Due to a slow convergence rate south of the CTJ 
( $18.5 \mathrm{~mm} / \mathrm{yr}$ compared to $66 \mathrm{~mm} / \mathrm{yr}$ north of the CTJ; Wang et al., 2007; Fig. 1), a much longer stress build up is required to achieve similar co-seismic slip (while this is also depending on the locking state, we cannot take it into account as this is unknown south of the CTJ). Moreover, Baker Fjord is located on the southern boundary of a slab window (i.e., there is no subducting oceanic slab north of the fjord for a latitudinal distance of $\sim 140 \mathrm{~km}$; Russo et al., 2010; Ramos and Kay, 1992), hence at the boundary of a rupture, where lower seismic intensities typically occur (e.g. Astroza et al., 2012) and where co-seismic turbidites are generally absent (Goldfinger et al., 2014). Hence, while a megathrust earthquake cannot be excluded as the cause for the mid-Holocene MTDs and megaturbidite, several factors seem to refute a megathrust trigger.

- (2) Intraslab earthquakes can lead to severe seismic shaking such as the $1939 M_{S} 7.8$ catastrophic earthquake in south-central Chile (macroseismic intensities up to IX; Beck et al., 1998). However, the lack of a subducting slab below Baker Fjord makes this type of earthquake an improbable trigger, especially as the Antarctic-Plate oceanic slab that is present just south of the study area does not extent into the earth's mantle (Russo et al., 2010).

- (3) The deposits discussed in this study could have been triggered by a crustal earthquake. In Aysén Fjord, for example, an $M_{W} 6.2$ earthquake (21 April 2007) on the LOFZ has produced macroseismic intensities of VI in an area over $30 \mathrm{~km}$ across (i.e., larger than the study area) (Naranjo et al., 2010). This event generated, apart from many onshore landslides (Sepúlveda et al., 2010), widespread offshore landslides in the fjord (Van Daele et al., 2013), as did similar prehistoric events during the Holocene (Wils et al., 2017). As the study area is located about $30 \mathrm{~km}$ to the south east of the southern extremity of the LOFZ (Cembrano et al., 1996; Thomson, 2002), an earthquake on the LOFZ is unlikely to have triggered the MTDs and megaturbidite studied here, even though the LOFZ can be considered very active (Lange et al., 2008). The left-lateral strike-slip fault along the Messier Channel (Fuenzalida, 1976; Ramos and Kay, 1992; Fig. 1) is more likely to have hosted the triggering earthquake, as it is located merely $15-20 \mathrm{~km}$ to the west of the study area. Based on the empirical attenuation relationship for crustal earthquakes by Bakun and Wentworth (1997), which has been applied previously in Chile (e.g. Moernaut et al., 2014), a macroseismic intensity of VI can be reached up to 33 and $46 \mathrm{~km}$ from the epicenter for $M_{W} 6$ and $M_{W} 6.5$ earthquakes, respectively. An earthquake of such magnitude - in the order of the $2007 M_{W} 6.2$ Aysén earthquake - on the southern extremity of the LOFZ or in the Messier Channel could thus have triggered the observed slope failures. Moreover, Glasser and Ghiglione (2009) have shown that fjord orientations in the region are strongly driven by the orientations of the structural framework of lineaments in the Patagonian fjords. Indeed, the channels with a NE-SW orientation that are connected to the studied western sub-basin (Fig. 2) have a similar orientation as the LOFZ at its southern extreme (Fig. 1), and may thus be related to the latter. Moreover, the main channel, that hosts the studied sub-basins, is linked to a structural lineament with a WNW-ESE orientation (Glasser and Ghiglione, 2009; Fig. 2) and can be traced to the main WNW-ESE oriented basin of Lake O'Higgins (130-200 km ESE of the fjord; Fig. 1). This structural lineament coincides almost exactly with the southern boundary of the slab window as imaged by Russo et al. (2010). The contrast between the absence of a subducting oceanic slab to the $\mathrm{NE}$, and presence of a slab to the SW of this lineament, results in increased crustal stresses in the area (Ramos and Kay, 1992), and thus seismic activity along the WNW-ESE structural lineament. We thus propose that a crustal earthquake near the study area, most likely on the Messier Channel fault, triggered the deposits described above.

In conclusion, the mid-Holocene seismically-triggered MTDs and megaturbidite in Baker Fjord may be the result of a megathrust, intraslab or crustal earthquake. However, due to low convergence rates of the Antarctic and South-American plates (18.5 mm/yr), and the presence of a slab window north of the study area, we argue that the most likely seismic trigger is a crustal earthquake. Since our study constitutes the first paleoseismic record south of the Chile Triple Junction, the event cannot be linked to any already known earthquake.

\section{Conclusions}

In this multiproxy study, we successfully reconstructed the depositional processes and determined the source and timing of a megaturbidite and associated deposits in Baker Fjord. A single event has created an MTD and a megaturbidite with a total thickness of $1924 \mathrm{~cm}$ in core MD07-3121. Eroding cohesive MTDs (unit B, zone II) were deposited before the megaturbidite (Unit C, zone IIIa). The remaining suspended sediment settled likely within the weeks/months that followed the event (zone IIIb). The confined fjord floor morphology led to thickening of the deposits and likely caused seiching.

The event occurred during the late mid-Holocene (55135211 cal yr BP). A GLOF trigger can be refuted as the bulk organic geochemistry $\left(\delta^{13} \mathrm{C}\right)$ and submarine features (slide scars) suggests an intrabasinal origin. Furthermore, the normal grading of the megaturbidite record an intrabasinal turbidity flow velocity profile. Synchronous slope failure in the different sub-basins indicates a seismic trigger for the deposits. Due to the large influence of background sedimentation and absence of other paleoseismological study in the region, it is however impossible to assess the intensity of the responsible earthquake. Although the source of the earthquake is still uncertain, we argue that it is most likely a crustal earthquake.

In this study we showed the presence of a massive seismicallytriggered sediment deposit in Baker Fjord which suggests the area south of $45^{\circ} 30^{\prime} \mathrm{S}$ is subject to substantial earthquakes. The sub-bottom profile shows additional units with chaotic, low amplitude reflectors that indicate the likely presence of other event deposits prior to the ones described in this study (Fig. 4). For instance, at $4000 \mathrm{~cm}$ depth in core MD07-3121, the magnetic susceptibility shows again a signature of a turbidite base (Fig. 4). To complement the global record of prehistoric earthquakes, fjord and lake sediments south of $45^{\circ} 30^{\prime} \mathrm{S}$ should be studied accordingly. Paleoenvironmental studies in the Baker Fjord area that necessitate a continuous sediment record will need thorough sub-bottom profiling investigation prior to coring.

\section{Acknowledgements}

This work was part of the first author's MSc thesis at Ghent University and was financed by FWO project G0D7916N "Paleo-GLOFs" to S.B. R.D.P.-H. and A.T.H. were funded by Iniciativa Científica Milenio NC120066, Fondecyt 1140536 and Fondap 15110009. We would like to thank the captain and crew of R/V Marion Dufresne for the successful 'PACHIDERME' MD/159 cruise. The lab assistance by Camille Wandres (LSCE, Paris) and Elke Vandekerkhove (UGent) is greatly acknowledged. We are indebted to the Laboratoire de Mesures Carbone 14 (LMC14) in Saclay (France) for handling the radiocarbon dating with Artemis, Xavier Morin from IPEV for the sub-bottom profile data and Naomi Harada together with the whole JAMSTEC team for the multibeam data gathered during the MR08-06 cruise onboard R/V Mirai. Carina Lange (UdeC, Chile) and Elisabeth Michel (LSCE, France) are acknowledged for constructive discussions. We thank Zakaria Ghazoui for his elaborate comments on the figures and the two anonymous reviewers for their constructive and insightful comments.

\section{Appendix A. Supplementary data}

Supplementary data to this article can be found online at https://doi. org/10.1016/j.sedgeo.2018.01.002. 


\section{References}

Agurto-Detzel, H., Rietbrock, A., Bataille, K., Miller, M., Iwamori, H., Priestley, K., 2014. Seismicity distribution in the vicinity of the Chile Triple Junction, Aysén Region, southern Chile. Journal of South American Earth Sciences 51, 1-11.

Aniya, M., 2013. Holocene glaciations of Hielo Patagónico (Patagonia Icefield), South America: A brief review. Geochemical Journal 47 (2), 97-105.

Astroza, M., Ruiz, S., Astroza, R., 2012. Damage assessment and seismic intensity analysis of the 2010 (Mw 8.8) Maule earthquake. Earthquake Spectra 28 (S1), S145-S164.

Baas, J.H., van Dam, R.L., Storms, J.E.A., 2000. Duration of deposition from decelerating high-density turbidity currents. Sedimentary Geology 136 (1-2), 71-88.

Bakun, W.U., Wentworth, C., 1997. Estimating earthquake location and magnitude from seismic intensity data. Bulletin of the Seismological Society of America 87 (6), 1502-1521.

Beck, S., Barrientos, S., Kausel, E., Reyes, M., 1998. Source characteristics of historic earthquakes along the central Chile subduction Askew et Alzone. Journal of South American Earth Sciences 11 (2), 115-129.

Bertrand, S., Charlet, F., Chapron, E., Fagel, N., De Batist, M., 2008. Reconstruction of the Holocene seismotectonic activity of the Southern Andes from seismites recorded in Lago Icalma, Chile, $39^{\circ} \mathrm{S}$. Palaeogeography, Palaeoclimatology, Palaeoecology 259 (2), 301-322.

Bird, P., 2003. An updated digital model of plate boundaries. Geochemistry, Geophysics, Geosystems 4 (3)

Blaauw, M., Christen, J.A., 2011. Flexible paleoclimate age-depth models using an autoregressive gamma process. Bayesian Analysis 6 (3), 457-474.

Bouma, A.H., 1987. Megaturbidite: an acceptable term? Geo-Marine Letters 7 (2), 63-67.

Boyd, B., Anderson, J., Wellner, J., Fernandez, R., 2008. The sedimentary record of glacia retreat, Marinelli Fjord, Patagonia: Regional correlations and climate ties. Marine Geology 255 (3), 165-178.

Branney, M.J., Gilbert, J.S., 1995. Ice-melt collapse pits and associated features in the 1991 lahar deposits of Volcán Hudson, Chile: criteria to distinguish eruption-induced glacier melt. Bulletin of Volcanology 57 (5), 293-302.

Campos, C., Beck, C., Crouzet, C., Demory, F., Van Welden, A., Eris, K., 2013. Deciphering hemipelagites from homogenites through anisotropy of magnetic susceptibility. Paleoseismic implications (Sea of Marmara and Gulf of Corinth). Sedimentary Geology 292, 1-14.

Campos, C., Beck, C., Crouzet, C., Carrillo, E., Van Welden, A., Tripsanas, E., 2014. Late Quaternary paleoseismic sedimentary archive from deep central Gulf of Corinth: time distribution of inferred earthquake-induced layers. Annals of Geophysics 56 (6)

Cande, S.C., Leslie, R.B., 1986. Late Cenozoic tectonics of the southern Chile trench. Journa of Geophysical Research: Solid Earth 91 (B1), 471-496.

Casassa, G., Wendt, J., Wendt, A., López, P., Schuler, T., Maas, H.-G., Carrasco, J., Rivera, A., 2010. Outburst floods of glacial lakes in Patagonia: is there an increasing trend? EGU General Assembly Conference Abstracts, p. 12821

Cembrano, J., Hervé, F., Lavenu, A., 1996. The Liquiñe Ofqui fault zone: a long-lived intraarc fault system in southern Chile. Tectonophysics 259 (1-3), 55-66.

Cembrano, J., Schermer, E., Lavenu, A., Sanhueza, A., 2000. Contrasting nature of deformation along an intra-arc shear zone, the Liquiñe-Ofqui fault zone, southern Chilean Andes. Tectonophysics 319 (2), 129-149.

Cembrano, J., Lavenu, A., Reynolds, P., Arancibia, G., López, G., Sanhueza, A., 2002. Late Cenozoic transpressional ductile deformation north of the Nazca-South AmericaAntarctica triple junction. Tectonophysics 354 (3), 289-314.

Chapron, E., Beck, C., Pourchet, M., Deconinck, J.F., 1999. 1822 earthquake-triggered homogenite in Lake Le Bourget (NW Alps). Terra Nova 11 (2-3), 86-92.

Chapron, E., Ariztegui, D., Mulsow, S., Villarosa, G., Pino, M., Outes, V., Juvignié, E., Crivelli, E., 2006. Impact of the 1960 major subduction earthquake in Northern Patagonia (Chile, Argentina). Quaternary International 158 (1), 58-71.

DaSilva, J.L., Anderson, J.B., Stravers, J., 1997. Seismic facies changes along a nearly continuous 24 latitudinal transect: the fjords of Chile and the northern Antarctic Peninsula. Marine Geology 143 (1-4), 103-123.

Diraison, M., Cobbold, P., Rossello, E., Amos, A., 1998. Neogene dextral transpression due to oblique convergence across the Andes of northwestern Patagonia, Argentina. Journal of South American Earth Sciences 11 (6), 519-532.

Douglass, D., Singer, B., Kaplan, M., Ackert, R., Mickelson, D., Caffee, M., 2005. Evidence of early Holocene glacial advances in southern South America from cosmogenic surfaceexposure dating. Geology 33 (3), 237-240.

Dowdeswell, J., Vásquez, M., 2013. Submarine landforms in the fjords of southern Chile: implications for glacimarine processes and sedimentation in a mild glacierinfluenced environment. Quaternary Science Reviews 64, 1-19.

Dussaillant, A., Benito, G., Buytaert, W., Carling, P., Meier, C., Espinoza, F., 2010. Repeated glacial-lake outburst floods in Patagonia: an increasing hazard? Natural Hazards 54 (2), 469-481.

Fanetti, D., Anselmetti, F.S., Chapron, E., Sturm, M., Vezzoli, L., 2008. Megaturbidite deposits in the Holocene basin fill of Lake Como (southern Alps, Italy). Palaeogeography, Palaeoclimatology, Palaeoecology 259 (2), 323-340.

Fogwill, C., Turney, C., Hutchinson, D., Taschetto, A., England, M., 2015. Obliquity contro on southern hemisphere climate during the last glacial. Scientific Reports 5, 11673.

Folk, R.L., Ward, W.C., 1957. Brazos River bar: a study in the significance of grain size parameters. Journal of Sedimentary Research 27 (1), 3-26.

Fontijn, K., Lachowycz, S.M., Rawson, H., Pyle, D.M., Mather, T.A., Naranjo, J.A., MorenoRoa, H., 2014. Late Quaternary tephrostratigraphy of southern Chile and Argentina. Quaternary Science Reviews 89, 70-84.

Forsythe, R., Nelson, E., 1985. Geological manifestations of ridge collision: Evidence from the Golfo de Penas-Taitao Basin, southern Chile. Tectonics 4 (5), 477-495.
Fuenzalida, P.R., 1976. The Magellan fault zone. In: Ferran, Gonzilez (Ed.), Symposium on Andean and Antarctic Volcanology Problems. International Association of Volcanology and Chemistry of Earth's interior. Special Series, pp. 373-391.

Garreaud, R., Lopez, P., Minvielle, M., Rojas, M., 2013. Large-scale control on the Patagonian climate. Journal of Climate 26 (1), 215-230.

Girardclos, S., Sturm, M., Schmidt, O., Ariztegui, D., Pugin, A., Anselmetti, F., 2006. A Catastrophic Event From a Non-catastrophic Cause: the 1996 AD Megaturbidite in Lake Brienz (Switzerland). AGU Fall Meeting Abstracts.

Girardclos, S., Schmidt, O.T., Sturm, M., Ariztegui, D., Pugin, A., Anselmetti, F.S., 2007. The 1996 AD delta collapse and large turbidite in Lake Brienz. Marine Geology 241 (1), 137-154.

Glasser, N.F., Ghiglione, M.C., 2009. Structural, tectonic and glaciological controls on the evolution of fjord landscapes. Geomorphology 105 (3), 291-302.

Glasser, N.F., Jansson, K.N., Harrison, S., Kleman, J., 2008. The glacial geomorphology and Pleistocene history of South America between $38 \mathrm{~S}$ and $56 \mathrm{~S}$. Quaternary Science Reviews 27 (3), 365-390.

Glasser, N.F., Harrison, S., Jansson, K.N., Anderson, K., Cowley, A., 2011. Global sea-level contribution from the Patagonian Icefields since the Little Ice Age maximum. Nature Geoscience 4 (5), 303-307.

Glasser, N.F., Jansson, K.N., Duller, G.A., Singarayer, J., Holloway, M., Harrison, S., 2016. Glacial lake drainage in Patagonia (13-8 kyr) and response of the adjacent Pacific Ocean. Scientific Reports 6, 21064.

Goldfinger, C., Nelson, C.H., Johnson, J.E., 2003. Holocene earthquake records from the Cascadia subduction zone and northern San Andreas fault based on precise dating of offshore turbidites. Annual Review of Earth and Planetary Sciences 31 (1), 555-577.

Goldfinger, C., Patton, J.R., Van Daele, M., Moernaut, J., Nelson, C.H., De Batist, M., Morey, A.E., 2014. Forum comment. Geology 42, e344

González, H., Castro, L., Daneri, G., Iriarte, J., Silva, N., Tapia, F., Teca, E., Vargas, C., 2013. Land-ocean gradient in haline stratification and its effects on plankton dynamics and trophic carbon fluxes in Chilean Patagonian fjords (47-50 S). Progress in Oceanography 119, 32-47.

Gutiérrez, F., Gioncada, A., Ferran, O.G., Lahsen, A., Mazzuoli, R., 2005. The Hudson Volcano and surrounding monogenetic centres (Chilean Patagonia): an example of volcanism associated with ridge-trench collision environment. Journal of Volcanology and Geothermal Research 145 (3), 207-233.

Haeussler, P.J., Parsons, T., Finlayson, D.P., Hart, P., Chaytor, J.D., Ryan, H., Lee, H., Labay, K., Peterson, A., Liberty, L., 2014. New imaging of submarine landslides from the 1964 earthquake near Whittier, Alaska, and a comparison to failures in other Alaskan fjords. Submarine Mass Movements and Their Consequences. Springer, pp. 361-370.

Harada, N., The Shipboard Scientific Party, 2008. MIRAI Cruise Report MR06-04 Leg 3. Japan Agency for Marine Earth Science and Technology, Yokosuka (176 pp.).

Hayes, G.P., Smoczyk, G.M., Benz, H.M., Furlong, K.P., Villaseñor, A., 2015. Seismicity of the Earth 1900-2013, seismotectonics of South America (Nazca Plate Region). US Geological Survey: Report Number 2331-1258.

Heiri, O., Lotter, A.F., Lemcke, G., 2001. Loss on ignition as a method for estimating organic and carbonate content in sediments: reproducibility and comparability of results. Journal of Paleolimnology 25 (1), 101-110.

Hogg, A.G., Hua, Q., Blackwell, P.G., Niu, M., Buck, C.E., Guilderson, T.P., Heaton, T.J., Palmer, J.G., Reimer, P.J., Reimer, R.W., 2013. SHCal13 Southern Hemisphere Calibration, $0-50,000$ years cal BP. Radiocarbon 55 (2), 1-15.

Jackson, C.A., 2011. Three-dimensional seismic analysis of megaclast deformation within a mass transport deposit; implications for debris flow kinematics. Geology 39 (3), 203-206.

Jansen, E., Overpeck, J., Briffa, K., Duplessy, J., Joos, F., Masson-Delmotte, V., Olago, D., OttoBliesner, B., Peltier, W., Rahmstorf, S., 2007. Paleoclimate. Climate change 2007: the physical science basis. Working Contribution of Working Group I to the Fourth Assessment Report of the Intergovernmental Panel on Climate Change.

Kassem, A., Imran, J., 2001. Simulation of turbid underflows generated by the plunging of a river. Geology 29 (7), 655-658

Kilian, R., Lamy, F., 2012. A review of Glacial and Holocene paleoclimate records from southernmost Patagonia $\left(49-55^{\circ} \mathrm{S}\right)$. Quaternary Science Reviews 53, 1-23.

Kissel, C., The Shipboard Scientific Party, 2007. MD159-PACHIDERME (IMAGES XV) Cruise Report. Série Les rapports de campagnes à la MerInstitut Paul-Emile Victor (105 pp.).

Kneller, B, Buckee, C, 2000. The structure and fluid mechanics of turbidity currents: a review of some recent studies and their geological implications. Sedimentology 47 (s1), $62-94$.

Lagabrielle, Y., Guivel, C., Maury, R.C., Bourgois, J., Fourcade, S., Martin, H., 2000. Magmatic-tectonic effects of high thermal regime at the site of active ridge subduction: the Chile Triple Junction model. Tectonophysics 326 (3), 255-268.

Lamb, A.L., Wilson, G.P., Leng, M.J., 2006. A review of coastal palaeoclimate and relative sea-level reconstructions using $\delta^{13} \mathrm{C}$ and $\mathrm{C} / \mathrm{N}$ ratios in organic material. EarthScience Reviews 75 (1), 29-57.

Lamy, F., Kaiser, J., Ninnemann, U., Hebbeln, D., Arz, H.W., Stoner, J., 2004. Antarctic timing of surface water changes off Chile and Patagonian ice sheet response. Science 304 (5679), 1959-1962.

Lange, D., Cembrano, J., Rietbrock, A., Haberland, C., Dahm, T., Bataille, K., 2008. First seismic record for intra-arc strike-slip tectonics along the Liquiñe-Ofqui fault zone at the obliquely convergent plate margin of the southern Andes. Tectonophysics 455 (1-4), $14-24$

Lara, L.E., 2010. The 2008 eruption of the Chaitén Volcano, Chile: a preliminary report. Andean Geology 36 (1), 125-130.

Lee, H., Ryan, H., Kayen, R.E., Haeussler, P.J., Dartnell, P., Hampton, M.A., 2006. Varieties of submarine failure morphologies of seismically-induced landslides in Alaskan fjords. Norwegian Journal of Geology/Norsk Geologisk Forening 86 (3), 221-230.

Legrand, D., Barrientos, S., Bataille, K., Cembrano, J., Pavez, A., 2011. The fluid-driven tectonic swarm of Aysen Fjord, Chile (2007) associated with two earthquakes (Mw = 
6.1 and $M w=6.2$ ) within the Liquiñe-Ofqui Fault Zone. Continental Shelf Research 31 (3-4), 154-161.

Leyton, F., Ruiz, J., Campos, J., Kausel, E., 2009. Intraplate and interplate earthquakes in Chilean subduction zone: A theoretical and observational comparison. Physics of the Earth and Planetary Interiors 175 (1), 37-46.

L'Heureux, J.-S., Longva, O., Hansen, L., Vanneste, M., 2014. The 1930 landslide in Orkdalsfjorden: morphology and failure mechanism. Submarine Mass Movements and Their Consequences. Springer, pp. 239-247.

Marín, V.H., Tironi, A., Paredes, M.A., Contreras, M., 2013. Modeling suspended solids in a Northern Chilean Patagonia glacier-fed fjord: GLOF scenarios under climate change conditions. Ecological Modelling 264, 7-16.

Mayr, C.C., Försterra, G., Häussermann, V., Wunderlich, A., Grau, J., Zieringer, M., Altenbach, A.V., 2011. Stable isotope variability in a Chilean fjord food web: implications for N-and C-cycles. Marine Ecology Progress Series 428, 89-104.

McCulloch, R., Bentley, M.J., Purves, R.S., Hulton, N.R., Sugden, D.E., Clapperton, C.M., 2000 Climatic inferences from glacial and palaeoecological evidence at the last glacial termination, southern South America. Journal of Quaternary Science 15 (4), 409-417.

McGarr, A., 1965. Excitation of seiches in channels by seismic waves. Journal of Geophysical Research 70 (4), 847-854

McHugh, C.M., Seeber, L., Braudy, N., Cormier, M.-H., Davis, M.B., Diebold, J.B., Dieudonne, N., Douilly, R., Gulick, S.P., Hornbach, M.J., 2011. Offshore sedimentary effects of the 12 January 2010 Haiti earthquake. Geology 39 (8), 723-726.

Moernaut, J., De Batist, M., Charlet, F., Heirman, K., Chapron, E., Pino, M., Brümmer, R. Urrutia, R., 2007. Giant earthquakes in South-Central Chile revealed by Holocene mass-wasting events in Lake Puyehue. Sedimentary Geology 195 (3), 239-256.

Moernaut, J., Daele, M.V., Heirman, K., Fontijn, K., Strasser, M., Pino, M., Urrutia, R., De Batist, M., 2014. Lacustrine turbidites as a tool for quantitative earthquake reconstruction: New evidence for a variable rupture mode in south central Chile. Journal of Geophysical Research: Solid Earth 119 (3), 1607-1633.

Moernaut, J., Van Daele, M., Fontijn, K., Heirman, K., Kempf, P., Pino, M., Valdebenito, G., Urrutia, R., Strasser, M., De Batist, M., 2018. Larger earthquakes recur more periodically: New insights in the megathrust earthquake cycle from lacustrine turbidite records in south-central Chile. Earth and Planetary Science Letters 481, 9-19.

Monecke, K., Anselmetti, F.S., Becker, A., Sturm, M., Giardini, D., 2004. The record of historic earthquakes in lake sediments of Central Switzerland. Tectonophysics 394 (1), 21-40.

Moreau, C., Caffy, I., Comby, C., Delqué-Kolic, E., Dumoulin, J., Hain, S., Quiles, A., Setti, V., Souprayen, C., Thellier, B., 2013. Research and development of the Artemis 14C AMS facility: status report. Radiocarbon 55 (2-3), 331-337.

Mulder, T., Alexander, J., 2001. The physical character of subaqueous sedimentary density flows and their deposits. Sedimentology 48 (2), 269-299.

Mulder, T., Syvitski, J.P., Skene, K.I., 1998. Modeling of erosion and deposition by turbidity currents generated at river mouths. Journal of Sedimentary Research 68 (1), 124-137.

Mulder, T., Migeon, S., Savoye, B., Faugères, J.-C., 2001. Inversely graded turbidite sequences in the deep Mediterranean: a record of deposits from flood-generated turbidity currents? Geo-Marine Letters 21 (2), 86-93.

Mulder, T., Syvitski, J.P.M., Migeon, S., Faugères, J.-C., Savoye, B., 2003. Marine hyperpycnal flows: initiation, behavior and related deposits. A review. Marine and Petroleum Geology 20 (6-8), 861-882.

Mulder, T., Zaragosi, S., Razin, P., Grelaud, C., Lanfumey, V., Bavoil, F., 2009. A new conceptual model for the deposition process of homogenite: Application to a cretaceous megaturbidite of the western Pyrenees (Basque region, SW France). Sedimentary Geology 222 (3), 263-273.

Murdie, R.E., Prior, D.J., Styles, P., Flint, S.S., Pearce, R.G., Agar, S.M., 1993. Seismic responses to ridge-transform subduction: Chile triple junction. Geology 21 (12), 1095-1098.

Naranjo, J.A., Stern, C.R., 1998. Holocene explosive activity of Hudson Volcano, southern Andes. Bulletin of Volcanology 59 (4), 291-306

Naranjo, J.A., Arenas, M., Clavero, J., Muñoz, O., 2010. Mass movement-induced tsunamis: main effects during the Patagonian Fjordland seismic crisis in Aisén $\left(45^{\circ} 25\right.$ 'S), Chile. Andean Geology 36 (1), 137-146.

Nimick, D.A., McGrath, D., Mahan, S.A., Friesen, B.A., Leidich, J., 2016. Latest Pleistocene and Holocene glacial events in the Colonia valley, Northern Patagonia Icefield, southern Chile. Journal of Quaternary Science 31 (6), 551-564.

Nisbet, E.G., Piper, D.J., 1998. Giant submarine landslides. Nature 392 (6674), 329-330.

Orihashi, Y., Naranjo, J.A., Motoki, A., Sumino, H., Hirata, D., Anma, R., Nagao, K., 2004 Quaternary volcanic activity of Hudson and Lautaro volcanoes, Chilean Patagonia: New constraints from K-Ar ages. Revista Geologica de Chile 31 (2), 207-224.

Pantoja, S., Iriarte, J.L., Daneri, G., 2011. Oceanography of the Chilean Patagonia. Continental Shelf Research 31 (3), 149-153.

Patacci, M., Haughton, P.D., Mccaffrey, W.D., 2015. Flow behavior of ponded turbidity currents. Journal of Sedimentary Research 85 (8), 885-902.

Perucca, L., Alvarado, P., Saez, M., 2015. Neotectonics and seismicity in southern Patagonia. Geological Journal 51 (4), 545-559.

Pickard, G., 1971. Some physical oceanographic features of inlets of Chile. Journal of the Fisheries Research Board of Canada 28 (8), 1077-1106.

Piret, L., Bertrand, S., Vandekerkhove, E., Harada, N., Moffat, C., Rivera, A., 2017. Gridded bathymetry of the Baker-Martinez fjord complex (Chile, $48^{\circ} \mathrm{S}$ ) v1. (figshare). https://doi.org/10.6084/m9.figshare.5285521.v1.

Praet, N., Moernaut, J., Van Daele, M., Boes, E., Haeussler, P.J., Strupler, M., Schmidt, S., Loso, M.G., De Batist, M., 2017. Paleoseismic potential of sublacustrine landslide records in a high-seismicity setting (south-central Alaska). Marine Geology 384 (Suppl. C), 103-119.

Ramos, V.A., Kay, S.M., 1992. Southern Patagonian plateau basalts and deformation: Backarc testimony of ridge collisions. Tectonophysics 205 (1), 261-282.
Rebolledo, L., Bertrand, S., Lange, C., Quiroga, E., Troch, M., Silva, N., Cardenas, P., Pantoja, S., Tapia, F., 2017. Sediment variations across the terrestrial-marine continuum of the Baker-Martínez fjord system (Chile, $48^{\circ} \mathrm{S}$ ). Progress in Oceanography (submitted for publication).

Russell, A.J., Knudsen, Ó., 1999. An ice-contact rhythmite (turbidite) succession deposited during the November 1996 catastrophic outburst flood (jökulhlaup), Skeiðarárjökull Iceland. Sedimentary Geology 127 (1), 1-10.

Russo, R., VanDecar, J.C., Comte, D., Mocanu, V.I., Gallego, A., Murdie, R.E., 2010. Subduc tion of the Chile Ridge: Upper mantle structure and flow. GSA Today 20 (9), 4-10.

Schnellmann, M., Anselmetti, F.S., Giardini, D., McKenzie, J.A., Ward, S.N., 2002. Prehistoric earthquake history revealed by lacustrine slump deposits. Geology 30 (12) 1131-1134.

Schnellmann, M., Anselmetti, F.S., Giardini, D., McKenzie, J.A., 2005. Mass movementinduced fold-and-thrust belt structures in unconsolidated sediments in Lake Lucerne (Switzerland). Sedimentology 52 (2), 271-289.

Sepúlveda, S.A., Serey, A., Lara, M., Pavez, A., Rebolledo, S., 2010. Landslides induced by the April 2007 Aysén fjord earthquake, Chilean Patagonia. Landslides 7 (4), 483-492.

Sievers, H., Silva, N., 2008. Water Masses and Circulation in Austral Chilean Channels and Fjords. Progress in the Oceanographic Knowledge of Chilean Interior Waters, From Puerto Montt to Cape Horn. Comité Oceanográfico Nacional-Pontificia Universidad Católica de Valparaíso, Valparaíso, pp. 53-58.

Sinclair, H., Tomasso, M., 2002. Depositional evolution of confined turbidite basins. Journal of Sedimentary Research 72 (4), 451-456.

Stacey, M.W., Bowen, A.J., 1988. The vertical structure of density and turbidity currents: theory and observations. Journal of Geophysical Research, Oceans 93 (C4), 3528-3542.

Stern, C.R., 2004. Active Andean volcanism: its geologic and tectonic setting. Revista Geologica de Chile 31 (2), 161-206.

St-Onge, G., Lajeunesse, P., 2007. Flood-induced turbidites from northern Hudson Bay and western Hudson Strait: a two-pulse record of Lake Agassiz final outburst flood? Submarine Mass Movements and Their Consequences, pp. 129-137

St-Onge, G., Mulder, T., Piper, D.J., Hillaire-Marcel, C., Stoner, J.S., 2004. Earthquake and flood-induced turbidites in the Saguenay Fjord (Québec): a Holocene paleoseismicity record. Quaternary Science Reviews 23 (3), 283-294.

St-Onge, G., Chapron, E., Mulsow, S., Salas, M., Viel, M., Debret, M., Foucher, A, Mulder, T. Winiarski, T., Desmet, M., 2012. Comparison of earthquake-triggered turbidites from the Saguenay (Eastern Canada) and Reloncavi (Chilean margin) Fjords: implications for paleoseismicity and sedimentology. Sedimentary Geology 243, 89-107.

Storchak, D., Di Giacomo, D., Engdahl, E., Harris, J., Bondár, I., Lee, W., Bormann, P., Villaseñor, A., 2015. The ISC-GEM global instrumental earthquake catalogue (1900-2009): introduction. Physics of the Earth and Planetary Interiors 239, 48-63.

Strasser, M. Anselmetti, F. S, Fäh, D. Giardini, D., Schnellmann, M., 2006. Magnitudes and source areas of large prehistoric northern Alpine earthquakes revealed by slope failures in lakes. Geology 34 (12), 1005-1008.

Stuiver, M., Polach, H.A., 1977. Discussion reporting of 14C data. Radiocarbon 19 (03), 355-363.

Sugden, D.E., Bentley, M.J., Fogwill, C., Hulton, N., McCulloch, R., Purves, R., 2005. Lateglacial glacier events in southernmost south america: a blend of 'northern' and 'southern' hemispheric climatic signals? Geografiska annaler: series a. Physical Geography 87 (2), 273-288.

Sugden, D.E., McCulloch, R.D., Bory, A.J.-M., Hein, A.S., 2009. Influence of Patagonian glaciers on Antarctic dust deposition during the last glacial period. Nature Geoscience 2 (4), 281-285.

Thomson, S.N., 2002. Late Cenozoic geomorphic and tectonic evolution of the Patagonian Andes between latitudes $42^{\circ} \mathrm{S}$ and $46^{\circ} \mathrm{S}$ : An appraisal based on fission-track results from the transpressional intra-arc Liquiñe-Ofqui fault zone. Geological Society of America Bulletin 114 (9), 1159-1173.

Turner, K., Fogwill, C., McCulloch, R., Sugden, D.E., 2005. Deglaciation of the eastern flank of the north patagonian icefield and associated continental-scale lake diversions. Geografiska Annaler. Series A, Physical Geography 87 (2), 363-374.

Usami, K., Ikehara, K., Jenkins, R.G., Ashi, J., 2017. Benthic foraminiferal evidence of deepsea sediment transport by the 2011 Tohoku-oki earthquake and tsunami. Marine Geology 384 (Suppl. C), 214-224.

Van Daele, M., Versteeg, W., Pino, M., Urrutia, R., De Batist, M., 2013. Widespread deformation of basin-plain sediments in Aysén fjord (Chile) due to impact by earthquake-triggered, onshore-generated mass movements. Marine Geology 337, 67-79.

Van Daele, M., Cnudde, V., Duyck, P., Pino, M., Urrutia, R., De Batist, M., 2014. Multidirectional, synchronously-triggered seismo-turbidites and debrites revealed by X-ray computed tomography (CT). Sedimentology 61 (4), 861-880.

Van Daele, M., Moernaut, J., Doom, L., Boes, E., Fontijn, K., Heirman, K., Vandoorne, W. Hebbeln, D., Pino, M., Urrutia, R., 2015. A comparison of the sedimentary records of the 1960 and 2010 great Chilean earthquakes in 17 lakes: Implications for quantitative lacustrine palaeoseismology. Sedimentology 62 (5), 1466-1496.

Van Daele, M., Meyer, I., Moernaut, J., De Decker, S., Verschuren, D., De Batist, M., 2017. A revised classification and terminology for stacked and amalgamated turbidites in environments dominated by (hemi) pelagic sedimentation. Sedimentary Geology 357, 72-82.

Wang, K., Hu, Y., Bevis, M., Kendrick, E., Smalley, R., Vargas, R.B., Lauría, E., 2007. Crustal motion in the zone of the 1960 Chile earthquake: Detangling earthquake-cycle deformation and forearc-sliver translation. Geochemistry, Geophysics, Geosystems 8 (10).

Weller, D., Miranda, C., Moreno, P., Villa-Martínez, R., Stern, C., 2014. The large late-glacia Ho eruption of the Hudson volcano, southern Chile. Bulletin of Volcanology 76 (6), 831.

Wenzens, G., 2005. Glacier advances east of the Southern Andes between the Last Glacial Maximum and 5,000 BP compared with lake terraces of the endorrheic 
Lago Cardiel ( $49^{\circ}$ S, Patagonia, Argentina). Zeitschrift für Geomorphologie NF 49 (4), 433-454

Wilhelm, B., Nomade, J., Crouzet, C., Litty, C., Sabatier, P., Belle, S., Rolland, Y., Revel, M. Courboulex, F., Arnaud, F., 2016. Quantified sensitivity of small lake sediments to record historic earthquakes: Implications for paleoseismology. Journal of Geophysical Research, Earth Surface 121 (1), 2-16

Wils, K., Van Daele, M., Lastras, G., Kissel, C., Lamy, F., Siani, G., 2017. Holocene event record of Aysén Fjord (Chilean Patagonia): an interplay of volcanic eruptions, crustal and megathrust earthquakes. Journal of Geophysical Research: Solid Earth 122.

Worni, R., Huggel, C., Clague, J.J., Schaub, Y., Stoffel, M., 2014. Coupling glacial lake impact, dam breach, and flood processes: A modeling perspective. Geomorphology 224 161-176.
Zavala, C., Arcuri, M., 2016. Intrabasinal and extrabasinal turbidites: Origin and distinctive characteristics. Sedimentary Geology 337, 36-54.

Zheng, Y., Kissel, C., Zheng, H., Laj, C., Wang, K., 2010. Sedimentation on the inner shelf of the East China Sea: magnetic properties, diagenesis and paleoclimate implications. Marine Geology 268 (1), 34-42.

Zuffa, G., Normark, W., Serra, F., Brunner, C.A., 2000. Turbidite megabeds in an oceanic rift valley recording jökulhlaups of late Pleistocene glacial lakes of the western United States. The Journal of Geology 108 (3), 253-274. 